\title{
TUTELA DEL CONSUMIDOR CONTRA CLÁUSULAS ABUSIVAS
}

\author{
REYLER YulFo RODRÍGUEZ CHÁVEZ*
}

\begin{abstract}
Resumen
En el presente trabajo se abordan los mecanismos de tutela del consumidor contra las cláusulas abusivas en los contratos de consumo que se hayan celebrado por adhesión o con arreglo a cláusulas generales de contratación. Estas modalidades contractuales imperantes en el mercado, si bien tienen la ventaja de establecer relaciones jurídicas patrimoniales entre proveedores y consumidores de manera rápida, eficiente y reduciendo al mínimo los costos de transacción (tiempo, dinero y esfuerzo que demanda contratar en el mercado), son contratos en los cuales el proveedor desarrolla todo su poder económico y su prevalencia en el manejo de la información, incluyendo en el contenido contractual cláusulas abusivas que desequilibran los derechos y obligaciones del consumidor, limitando, reduciendo o excluyendo sus derechos, o aumentando su obligaciones y cargas contractuales en contravención a la buena fe y el equilibrio contractual. Para hacer frente a las cláusulas abusivas se han instituido un conjunto de mecanismos de tutela del consumidor, que van desde la tutela privada a cargo del consumidor directamente perjudicado o mediante asociaciones representativas de los consumidores e incluso mediante el llamado autocontrol a cargo de los propios proveedores, así como también, se cuenta con mecanismos de tutela estatales, agrupados en controles de tipo administrativo, legislativo y judicial. La finalidad de todos estos mecanismos de tutela es la de proteger al consumidor previniendo o, en su caso, contrarrestando los efectos perjudiciales que las cláusulas abusivas causen en el contrato de consumo.
\end{abstract}

Palabras clave: Tutela - Consumidor - Cláusula, abusiva.

\begin{abstract}
In this paper, we address the existing consumer protection mechanisms against abusive clauses in consumer contracts adopted in line with or pursuant to general contracting laws. Although, these contractual modalities currently reigning in the market have the advantage of establishing quick and efficient legal reiationships between suppliers and consumers, thereby reducing costs of transactions to a minimum (time, money and effort invested in entering into contracts in the market), they are contracts in which suppliers develop all of their financial power and their prevalence in the management of information, including abusive clauses in contracts that disturb the balance between the rights and obligations of consumers, thereby restricting, reducing or excluding their rights or increasing their contractual obligations and costs, in violation of the principle of good faith and contractual fairness. To counteract abusive clauses, a set of consumer protection measures have been implemented, ranging from the protection of private interests of directly wronged consumers to consumer representative associations, and even to the so-called self restraint of suppliers. The state has also implemented
\end{abstract}

* Juez de Paz Letrado Titular de la Corte Superior de Justicia de Lima Norte - Poder Judicial del Perú. 
protection measures, grouped in controls of an administrative, legislative and judicial nature, aimed at protecting consumers by preventing or, if necessary, counteracting the harmful effects of abusive contractual terms in consumer contracts.

Key words: Protection - Consumer - Abusive Clause.

\section{Sumario}

1.- Introducción: Fundamento de la Tutela del Consumidor. 2.- Las cláusulas abusivas como presupuesto de los Sistemas Control. 3.- Sistemas de tutela del consumidor contra cláusulas abusivas.3.1.-Precisión necesaria.3.2.-Definición de los sistemas de tutela contra cláusulas abusivas. 3.3.- Modalidades de los sistemas de tutela del consumidor contra cláusulas abusivas. 3.3.1.- Tutela autónoma o paraestatal: a) Defensa individual del consumidor. b) Tutela colectiva del consumidor. c) El autocontrol del proveedor. 3.3.2.- Tutela estatal del consumidor. 4.- Tutela estatal del consumidor. 4.1.- El control administrativo. 4.1.1.- Definición. 4.1.2.- Características: a) Es un sistema de control previo. b) Es un control preventivo. c) Es un control evaluador. d) Es un sistema de control estatal. 4.1.3.- Entidad competente. 4.1.4.- El control administrativo en el Código de Protección y Defensa del Consumidor y en el Código Civil. a) La aprobación administrativa de las cláusulas generales de contratación. b) Las cláusulas generales de contratación no aprobadas administrativamente. 4.1.5. Tutela administrativa contra cláusulas abusivas. 4.2.- El control legislativo. 4.2.1.- Definición. 4.2.2.- Características del control legislativo: a) Es un control ex-ante. b) Permite regular los aspectos más importantes en relación a los contratos de consumo. c) Establece un catálogo de supuestos de cláusulas abusivas de ineficacia absoluta. d) Establece un catálogo de supuestos de cláusulas abusivas de ineficacia relativa. e) Otorga pautas generales al control administrativo y al control judicial. 4.2.3. Métodos de control legislativo: a) La cláusula general. b) La lista negra de cláusulas abusivas y sus efectos. c) La lista gris de cláusulas abusivas y sus efectos. 4.3.- El control judicial. 4.3.1.Definición. 4.3.2 Características: a) Es un mecanismo de control posterior. b) Es un mecanismo generado. c) Es un mecanismo evaluador. d) Es un mecanismo declarativo. e) Es un mecanismo integrador y reparador. 4.3.3.- Mecanismos de control judicial: criterios de interpretación de los contratos de consumo celebrados por adhesión y/o con arreglo a cláusulas generales de contratación.-a) Interpretación pro consumidor o favor debilis. b) La interpretatio contra stipulatorem. c) Principio de la buena fe. d) La cláusula prevalente. e) La cláusula más beneficiosa. f) La cláusula más importante. 5.- Conclusiones. 6.- Referencias Bibliográficas.

\section{INTRODUCCIÓN: FUNDAMENTO DE LA TUTELA DEL CONSUMIDOR}

El contrato de consumo se caracteriza por la intervención de dos sujetos o polos contractuales, uno que es especialista y profesional en el mercado y a quien se denomina proveedor y otro, que no tiene tal experiencia, que 
en la mayoría de casos es neófita en el campo comercial, y a quien se denomina consumidor. El proveedor conoce al detalle, de manera minuciosa el procedimiento, los componentes, elementos, cantidades, ingredientes, sustancias naturales o químicas, pesos y medidas, usos permitidos y prohibidos, alcances y limitaciones, efectos en la salud y psicológicos, etc., de los productos que produce o de los servicios que ofrece en el mercado, pues es su negocio y está obligado a conocer todos los detalles para tener éxito y no perecer en el comercio. La razón es simple, su interés y su presencia en el mercado se debe a que busca "maximizar" sus ganancias y para ello estará dispuesto a realizar todo tipo de actividades y utilizar todo tipo de medios, permisibles o no, legales o no, para obtener dicho propósito maximizador.

Pero en el mercado, también existen los consumidores quienes por lo general no son especialistas en el producto que consumen o en el servicio que utilizan, no tienen el conocimiento al detalle sobre los productos o servicios que con el fin de satisfacer sus diferentes necesidades adquieren en el mercado. Pero el consumidor también tiene un objetivo maximizador que podemos resumirlo con una frase común, que los productos o servicios reúnan "las tres B": bueno, bonito y barato. Bueno, en el sentido que permita al consumidor satisfacer sus necesidades de una manera satisfactoria. Bonito, que sea del gusto, agrado o llame la atención del consumidor. Barato, que sea accesible para la economía del consumidor y, de ser posible, que el producto o servicio se obtenga con la mayor rebaja.

El primer elemento que prima en el contrato de consumo entonces, es el manejo de una información respecto al producto o servicio que se caracteriza por ser desigual: el Proveedor posee más información y el consumidor posee menos información. A dicho desequilibro se denomina "asimetría informativa".

La otra característica del contrato de consumo es la forma o el ropaje con que éste se presenta en el mercado, siendo el medio más común que se utiliza la denominada contratación masiva, que permite a través de innumerables transacciones efectivizar la mayor parte de intercambios entre consumidores y proveedores en el mercado, en cuyo contexto, masas de consumidores casi al unísono, demandan grandes cantidades de productos o servicios, siendo el bloque de proveedores los encargados de ofertar tantos productos o servicios sean requeridos. Ambos polos logran atraerse jurídicamente mediante la contratación masiva que efectiviza el consumo de productos y servicios, siendo los contratos por adhesión y los contratos celebrados con arreglo a 
cláusulas generales de contratación, dos de las manifestaciones más comunes de la contratación masiva ${ }^{1}$.

En la génesis del contrato de consumo que se da bajo aquellas formas de contratación masiva, se halla implícito como fuente de autoría del mismo el poder de una de las partes, el proveedor, predisponente de las cláusulas que conforman la estructura del contrato. Así, una de las principales características del contrato de consumo como contrato masivo es "la limitación o falta de negociación" en la formulación del contrato. Sobre este punto el recordado maestro DE LA PUENTE destacaba que "el contenido del contrato ya no es el producto, el resultado del acuerdo conjunto de las partes, sino que éste es predispuesto total o parcialmente por una sola de ellas con antelación a su celebración" ${ }^{2}$. En el caso de los contratos de consumo, es el proveedor quien se irroga en forma exclusiva y excluyente la facultad para diseñar y redactar el contenido del contrato.

Lo que prima en el contrato de consumo que opera bajo esquemas contractuales masivos es la presencia de una "fórmula" previamente elaborada de manera unilateral por el proveedor, que en términos de GORLA, representa una "restricción" que se emplaza a la libertad contractual o de autorregulación negocial cuando una de las partes, por no ser igual y, por ende, libre, carece del poder de participar en la redacción del contrato que viene, finalmente, predispuesto por quien ocupa una posición contractual predominante ${ }^{3}$.

Este peculiar estatus que ocupa el proveedor en el contrato de consumo lo coloca en una posición de ventaja que le permite diseñar el contenido contractual, aprovechando así la oportunidad para acomodar sus intereses en

\footnotetext{
1 La contratación masiva es un mecanismo contractual de intercambio masivo que hace posible la concatenación de dos factores concurrentes, la producción masiva de bienes y servicios y el consumo masivo, dotándoles de vinculación jurídica. Constituye una forma de contratación a través de esquemas redactados previamente a su celebración por una de las partes. Este medio de contratación limita y en ciertos casos no admite ningún margen de negociación del contenido del contrato para una de las partes, el adherente o consumidor, pues lo que prima es la predisposición del esquema contractual; sin embargo, a cambio, otorga rapidez en la contratación y mayor eficiencia al reducir los costos de transacción en el mercado. ALPA señala que "la diferenciación de los contratos de los consumidores implica, por lo tanto, la adopción de una perspectiva más articulada respecto a aquella hasta hoy asumida por la doctrina sobre la materia: no se puede enunciar una teoría unitaria y monopólica de "contrato en general", siendo necesario -cuanto menos con respecto a la formación, al clausulado, a la interpretación y a la ejecución del contrato- distinguir la hipótesis del contrato con base individual y de los contratos entre empresarios, o entre los profesionales, para los cuales vale el derecho común, y la hipótesis de los contratos de los consumidores, para los cuales vale, en cambio el régimen especial”, En: ALPA, Guido; «Derecho del Consumidor», Gaceta Jurídica Editores, Juan ESPINOZA ESPINOZA - traductor, Lima, 2004, p., 214 y 215.

2 De la Puente y Lavalle, Manuel; «El Contrato en General», Palestra Editores, Lima, 2001, Tomo I, p. 71.

3 Citado por: StiglitZ, Rubén S. y STIGLiTZ, Gabriel A.; "Contratos por Adhesión, Cláusulas Abusivas y Protección al Consumidor», Editorial Depalma, Argentina, 1985, p. 28.
} 
procura de ventajas a costa de su contraparte en el contrato, el consumidor o receptor del esquema contractual elaborado por aquél.

Así entonces, el contrato de consumo que por lo general se celebra mediante contratos por adhesión o sujeto a cláusulas generales de contratación, en la práctica no hace sino viabilizar la asimetría informativa y el dominio del proveedor en la redacción del contrato.

Este es el escenario ideal donde tienen lugar las denominadas cláusulas abusivas. Pues el contrato de consumo, dada la superioridad del proveedor, es en realidad el instrumento perfecto donde aquél puede obtener ventajas desmedidas a costa y en perjuicio del consumidor, imponiendo cláusulas abusivas en el contenido contractual. Este tipo de cláusulas como lo destaca Di IORIO, "resulta consecuencia del predominio de una de las partes que le permite conducir toda la operación e imponer cláusulas que derogan los principios generales establecidos por la ley, reemplazándolos por cláusulas opresivas, contrarias al principio de la buena fe, que terminan por afectar la equivalencia de los intereses bilaterales" ${ }^{4}$.

No obstante, la presencia de las cláusulas abusivas en el contrato de consumo y sobre todo los nocivos efectos que producen en los derechos del consumidor, precisamente ha motivado el establecimiento de un conjunto de pilares de tutela del consumidor desde diversos frentes y cuyo cometido común es el de prevenir o restablecer las desigualdades que se acentúan y agravan con la presencia de cláusula abusivas en el contrato de consumo.

\section{LAS ClÁUSUlas AbUSiVAS COMO PRESUPUESTO DE LOS SISTEMAS CONTROL}

La manera en que el proveedor consolida su sola voluntad, es justamente mediante la inclusión en el contrato de consumo de cláusulas abusivas. Como destacan los STIGLITZ, estas cláusulas se incorporan con la finalidad inequívoca "de consolidar la posición contractual del predisponente con una

\footnotetext{
4 Di IORIO, Alfredo J.; «Las cláusulas generales de contratación en el código civil peruano y el ordenamiento jurídico latinoamericano», En: El Código Civil Peruano y el Sistema Jurídico Latinoamericano, Editorial Cultural Cuzco, Lima, 1985, p. 413. Es importante ver la perspectiva de MORALES, quien señala que los contratos de consumo se caracterizan por su carácter potencialmente abusivo y por tanto desequilibrado de algunas de estas cláusulas (clauses abusives, unfair termns, clausole vessatorie), así como su crítica respecto a la defectuosa definición que sobre el contrato de consumo hace el art. $45^{\circ}$ del Código de Protección y Defensa del Consumidor, Véase: MORALES HeRvias, Rómulo; «La definición del contrato de consumo en el Código de Protección y Defensa del Consumidor», En: Actualidad Jurídica, Gaceta Jurídica Editores, Setiembre, 2010, p. 35.
} 
sobreviniente situación de desequilibrio debido a la falta de reciprocidad en las prestaciones debidas y, correlativamente con la inclusión de ventajas que solamente se estipulan en beneficio del predisponente" ${ }^{5}$.

El poder que ostenta el proveedor y que se ve reflejado en el completo dominio de la esfera contractual, es el que le permite muchas veces cometer excesos y abusos en desmedro del consumidor. REZZÓnICO precisa que "es a través de las diversas cláusulas específicas como el estipulante lleva a la práctica, fundamentalmente, su situación de ventajoso predominio negocial: excluyendo la responsabilidad, imponiendo un régimen arbitrario para la carga de la prueba, fijando plazos excesivamente cortos para el ejercicio de las eventuales acciones" ${ }^{\prime \prime}$.

BRICKS alcanza que son abusivas las cláusulas que entrañen en ventaja exclusiva del empresario un desequilibrio de los derechos y obligaciones de las partes siempre que lo sea en un contrato por adhesión concluido entre un empresario y un consumidor, unilateralmente prerredactado por el primero ${ }^{7}$. SOTO las define señalando que "se considerarán abusivas todas las cláusulas o condiciones de los contratos predispuestos que atribuyan al predisponente derechos y facultades exorbitantes o introduzcan limitaciones o restricciones en los derechos y facultades de los adherentes. Igualmente, serán abusivas las cláusulas que supriman o reduzcan las obligaciones y responsabilidades del predisponente o cuando aumenten las obligaciones y cargas del adherente, trayendo como consecuencia una desnaturalización o desequilibrio en la relación jurídica creada por el contrato ${ }^{8}$.

En este sentido, podrá ser considerada como abusiva, aquella cláusula o conjunto de ellas que en la relación de consumo concretada mediante contratos por adhesión o con arreglo a cláusulas generales de contratación, impongan un desbalance en los derechos y obligaciones del proveedor y consumidor, con el objeto de reflejar beneficios exclusivos o excesivos para el proveedor a costa del consumidor.

5 Stiglitz, Rubén S. y Stiglitz, Gabriel A.; cit., p. 96.

6 RezzónICO, Juan Carlos; "Contratos con Cláusulas Predispuestas. Condiciones Negociales Generales», Editorial Astrea, Buenos Aires, 1987, p. 449.

7 Cita de: StiglitZ, Rubén S. y STIGLITZ, Gabriel A.; cit., p. 95.

8 Sото, Carlos Alberto; «Las cláusulas generales de contratación y las cláusulas abusivas en los contratos predispuestos», En: Contratación Privada, Soto Coaguila, Carlos Alberto y Jiménez Vargas-Machuca, Roxana: coordinadores, Editorial Jurista, Lima, 2002, p. 237. DE LA PUENTE entendía que una cláusula abusiva debe ser interpretada como excesiva u onerosa, que reporta una ventaja indiscriminada a favor de uno de los contratantes en menoscabo del otro, De LA PuENTE y Lavalle, Manuel; El Contrato en General, cit., p. 784. 
Nuestro Código de Protección y Defensa del Consumidor parece haber limitado la concepción de cláusula abusiva a aquellas estipulaciones "no negociadas individualmente" que tienen lugar en el ámbito de los contratos por adhesión y de las cláusulas generales de contratación, y que "no hayan sido aprobadas administrativamente", conforme se puede apreciar del artículo $40^{\circ}$ del Código citado.

Las cláusulas abusivas materializan situaciones de desequilibrio o desigualdad en la titularidad de los derechos y obligaciones. Pues por un lado, la situación de superioridad del proveedor le permite autoconcederse mayores derechos o facultades, o, reducir, limitar o exonerar, total o parcialmente, sus obligaciones o cargas contractuales ${ }^{9}$. En tanto que del otro lado de la palestra, se concreta y acentúa una situación de desventaja injustificada para el consumidor expresada mediante el incremento excesivo de sus obligaciones y cargas, o, la limitación o supresión de sus derechos o facultades contractuales ${ }^{10}$.

Para determinar el carácter abusivo de una cláusula contractual, la tendencia básicamente ha sido la de fijar ciertos criterios o parámetros en base a los cuales sea factible determinar cuándo una cláusula es abusiva y cuándo no. Como principales criterios encontramos la existencia de un "desequilibrio injustificado en los derechos y obligaciones de las partes" que se deriven del contrato, la directa "contravención al principio de la buena fe contractual o al principio de la equidad", la "contravención a las normas de orden público y a las buenas costumbres"11.

Nuestro Código de Protección y Defensa del Consumidor en su artículo $49^{\circ}$ ha recogido como criterios para calificar como abusivas las cláusulas que "contravengan las exigencias de la buena fe" y "generen una situación de desventaja o desigualdad o anulen los derechos del consumidor".

\footnotetext{
9 En esta faceta de la cláusula abusiva, es el proveedor, estipulante del contrato, quien se irroga para sî mismo una serie de ventajas, que configuran luego un evidente desequilibrio en relación a la posición de su contraparte en el contrato de consumo.

10 En el mismo sentido destaca Diez PICAZO, Luis; «Fundamentos de Derecho Civil Patrimonial», Quinta edición, Editorial Civitas, Madrid, Volumen primero, 1996, pp. 380-381.

11 De CASTRO alude a las condiciones generales contrarias a la buena fe y a las buenas costumbres o por constituir un abuso de derecho, Véase DE CASTRO y BRAVO, Federico; «Las Condiciones Generales de los Contratos y la Eficacia de las Leyes», Segunda edición, Editorial Civitas, Madrid, 1987, p. 76. SOTO considera como criterios: a) una desviación del principio de la buena fe contractual, b) una desnaturalización o desequilibrio de la relación contractual, c) un detrimento o perjuicio en contra del adherente al esquema contractual y, d) una atribución exorbitante en favor del predisponerte del esquema contractual, SOTO COAGUILA, Carlos Alberto; “Las cláusulas generales de contratación y las cláusulas abusivas en los contratos predispuestos", cit., p. 237.
} 


\section{SISTEMAS DE TUTELA DEL CONSUMIDOR CONTRA CLÁUSULAS ABUSIVAS}

\subsection{Precisión necesaria}

Es pertinente señalar que la razón que ha justificado el enorme desarrollo y el interés por la implementación de mecanismos de tutela del consumidor contra las cláusula abusivas en los diversos ordenamientos jurídicos, ha sido precisamente la necesidad de evitar que mediante el empleo de contratos de consumo celebrados bajo la modalidad de adhesión o con arreglo a cláusulas generales de contratación, se haga uso indiscriminado de estipulaciones o cláusulas que por lo general al obedecer al designio unilateral del proveedor, conlleven inevitablemente a causar un grave perjuicio en desmedro de los consumidores. De allí que sostengamos que es esencialmente la necesidad de prevenir la existencia de cláusulas abusivas o de contrarrestar las ya existentes, la razón que se consolida como presupuesto de los sistemas de control, concretamente en los contratos de consumo celebrados por adhesión o con arreglo a las cláusulas generales de contratación.

DiEZ PICAZO ha comentado el tema en relación a los contratos por adhesión, en los cuales se acentúa poder unilateral del predisponente, señalando que el problema esencial respecto a ellos reside en la articulación de un régimen jurídico que haga posible el deseo de evitar o en su caso suprimir los posibles abusos que se puedan generar por la situación preponderante de una de las partes $^{12}$.

Es pues, la debilidad contractual o estado de desventaja en que se halla el consumidor, y que principalmente se consolida mediante la inclusión en el contrato de cláusulas abusivas por parte del proveedor, la causa motriz de los sistemas jurídicos de control, cuya función contra ellas está destinada a evitar su presencia o a contrarrestar sus consecuencias, dejándolas sin efecto, privándolas de la posibilidad de concretar el abuso contra el consumidor.

\subsection{Definición de los sistemas de tutela contra cláusulas abusivas}

Los sistemas de control son aquellos mecanismos con relevancia jurídica que de manera preventiva o en forma posterior, pública o privada, y en forma complementaria y coordinada, buscan evitar la existencia de excesos que pudieran generarse por la eventual presencia de cláusulas abusivas, o a

\footnotetext{
12 Diez PICAZO, Luis; Volumen primero, cit., p. 350.
} 
contrarrestar aquellos abusos de haberse ya producido, con el único fin de mantener en pie o, en su caso, de restablecer el equilibrio contractual entre los derechos y obligaciones de las partes.

Bajo esa premisa, el control contra las cláusulas abusivas puede darse en dos momentos, de manera previa, cuando se vigila que el futuro contenido de los contratos de consumo a celebrarse por adhesión o con arreglo a cláusulas generales de contratación, antes de entrar en el tráfico mercantil, no contengan cláusulas abusivas, y de manera posterior; cuando una vez celebrado el contrato y al haberse corroborado la existencia de cláusulas abusivas, se busca como objetivo dejarlas sin efecto y restablecer el desequilibrio que hayan generado ${ }^{13}$.

\subsection{Modalidades de los sistemas de tutela del consumidor contra cláusulas abusivas}

\subsubsection{Tutela autónoma o paraestatal}

Esta forma de control es ejercida al margen de toda intervención estatal directa. La titularidad corresponde a los particulares, sea individualmente o en forma grupal. De lo que se trata aquí señala GALGANO, es "de institucionalizar las técnicas participativas de la comunidad, que coloquen en manos de los grupos humanos ciertos poderes eficientes de acción y reacción con relación a los sectores empresariales" ${ }^{\prime 4}$. Son los ciudadanos los que, al entrar inevitablemente en relaciones de consumo masivo, se han visto en la necesidad de implementar determinados mecanismos para autoprotegerse de los proveedores que ostentan el mayor poder negocial en el escenario contractual.

AMAYA alcanza que ese control paraestatal o autónomo es un mecanismo de autotutela de los consumidores que individual o colectivamente a través de sus asociaciones, buscan la posibilidad de imponer su voluntad negocial a la contraparte que se halla generalmente en una situación de superioridad ${ }^{15}$.

\footnotetext{
${ }^{13}$ GALDós tomando como base el derecho a la igualdad refiere con aguda inferencia que en este caso el orden jurídico concurre para nivelar las desigualdades y consagrar, sobre todo en casos dudosos, normas de protección del débil o del vulnerable a fines de conferir operatividad al mandato constitucional de la igualdad ante la ley, GALDÓs, Jorge Mario; «El principio favor débilis en materia contractual. Algunas aproximaciones en el derecho argentino», En: Contratación Privada, (Soto Coaguila, Carlos Alberto y Roxana Jiménez Vargas-Machuca: coordinadores), Editorial Jurista, Lima-Perú, 2002, p. 141.

14 Cita de: STIGLITZ, Rubén S. y STIGLITZ, Gabriel A.; cit., p. 17.

15 Amaya AYALA, Leoni Raúl; «La letra pequeña que nadie lee. Sistemas de control contra las cláusulas abusivas», En: Revista Actualidad Jurídica, Gaceta Jurídica, Tomo 120, Lima, Noviembre 2003, p. 54.
} 


\section{a) Defensa individual del consumidor:}

El control autónomo puede ser ejercido de manera individual cuando el propio consumidor perjudicado con el abuso o que se halla en situación de desequilibrio, ejerce determinadas acciones de protección contra cualquier abuso injustificado que se presente en el contrato. Los STIGLITZ postulan que la acción individual corresponde al consumidor afectado que opta por hacer valer de ese modo la fracción del interés grupal que personalmente le compete ${ }^{16}$.

SOTO afirma que esta defensa individual contra las cláusulas abusivas se realiza mediante el ejercicio de su libertad de contratación, que le permitirá decidir si contrata o no bajo determinadas condiciones, pues nadie está obligado a contratar. Sin embargo, el mismo autor considera que esta forma de defensa, dadas las características del tráfico masivo, resulta mayormente inviable, pues la necesidad de la adquisición de bienes y servicios básicos, que se encuentran monopolizados, "obligan" a contratar "sí o sí" a los consumidores o usuarios, sin dejar otra alternativa ${ }^{17}$.

Por otro lado, debemos señalar que el control individual no siempre tiene carácter preventivo, dada la limitada fuerza de presión que se tiene frente al empresario, por lo que comúnmente solo queda recurrir después de celebrado el contrato por adhesión o con arreglo a cláusulas generales de contratación, a los mecanismos de tutela que para tal efecto han previsto las diferentes normas como el Código de Protección y Defensa del Consumidor ${ }^{18}$.

Sobre este mecanismo de control, el Código de Protección y Defensa del Consumidor establece en el artículo $107^{\circ}$ que el proceso por infracción a los derechos del consumidor ante INDECOPI, como el derecho a que en los contratos de consumo por adhesión o sujetos a cláusulas generales

\footnotetext{
16 StiglitZ, Rubén S. y STigLiTZ, Gabriel A.; cit., p. 258.

17 Soto CoAguila, Carlos Alberto; «Las cláusulas generales de contratación y las cláusulas abusivas en los contratos predispuestos», cit., p. 238-239.

${ }^{18}$ Los STIGLITZ comentan que el desaliento del consumidor individual para presentar reclamos frente a las empresas se debe: a) la soledad del consumidor, b) obstáculos de naturaleza psicológica, ligado a la falta de conciencia de cuáles son sus derechos, cuando son vulnerados y sobre la posibilidad de accionar mecanismos judiciales de defensa, ausencia de conocimientos técnicos y jurídicos, resistencia a consultar al abogado, etc. c) exigüidad de la lesión, cuando el asunto por su escasa importancia económica no justifica del consumidor la reparación del aquel costo psicológico que implica la decisión de demandar, d) el carácter misterioso de la justicia, dado el vocabulario y formalidades del proceso, e) la lentitud de la justicia, f) los gastos de la justicia, lleva al consumidor a resignar la idea de hacer reconocer sus derechos por las vías legales, Véase: StiglitZ, Rubén S. y STigLiTZ, Gabriel A.; cit., p. 260.
} 
de contratación no contengan cláusulas abusivas, puede ser iniciado a instancia del consumidor lesionado, pudiendo en el proceso participar activamente, e interponer los recursos y solicitudes que crea pertinente a su derecho. Incluso, el consumidor lesionado podrá formular su reclamo o queja directamente ante el proveedor, solicitando para ello el libro de reclamaciones, el mismo que debe ser remitido por los establecimientos comerciales al INDECOPI, tal como lo estipula el artículo $152^{\circ}$ del Código analizado.

\section{b) Tutela colectiva del consumidor:}

De otro lado, encontramos al control colectivo, que es aquel que se realiza a través de las agrupaciones o asociaciones de consumidores, entidades que encarnan la tarea de protección contra una serie de abusos en las relaciones contractuales masivas, en algunos casos solo a sus asociados o integrantes y, en otros, incluso a quienes se hallan fuera de sus listas. Está caracterizado principalmente porque lo conforman una pluralidad de consumidores, la existencia de una organización colectiva y el respaldo ciudadano e incluso estatal, elementos que en conjunto dotan a esta forma de defensa el soporte necesario para hace frente a las grandes corporaciones, monopolios o el poder abusivo de los empresarios.

La intervención grupal está permitida pues cuando de los derechos de los consumidores se trata, estamos frente a un interés difuso, digno de tutela y amparo. AlPA estima que el interés difuso es una "fictio iuris" que se traduce en la "expresión resumida de todos los intereses individuales" y cuyo objetivo es volver relevantes todos aquellos intereses individuales que no serían accionados y protegidos por la inercia, por la indiferencia o las limitaciones del individuo ${ }^{19}$. De allí que la lesión o el abuso del interés individual conllevan, inevitablemente, a la lesión del interés grupal o difuso cuya titularidad corresponde a todos en general y a nadie en particular.

Generalmente estas agrupaciones de defensa de los consumidores actúan como una fuerza de contrapeso frente al autor de los contratos de consumo, con el objeto de lograr ciertos remedios en los contratos

\footnotetext{
${ }_{19}$ Cita de: AMAYA AYALA, Leoni Raúl; cit., p. 59. ViTTORIO señala que el interés difuso sirve, "para calificar a los que pertenecen indistintamente a una pluralidad de sujetos, en cuanto integrantes de una comunidad conformada alrededor de un ligamen objetivo: la pretensión de goce, por parte de cada uno de ellos, de una misma prerrogativa, en virtud de la indivisibilidad de los bienes perseguidos, por su naturaleza insusceptibles de apropiación exclusiva", Cita de: STIGLITZ, Rubén S. y STIGLITZ, Gabriel A.; Ob. cit., p. 14.
} 
a favor el público consumidor. RIPERT comenta que estas agrupaciones "se han hecho permanentes y organizadas. Agrupaciones de interesados hablan en nombre de todos, se encuentran en relaciones constantes con los parlamentarios, saben rogar, exigir, amenazar" ${ }^{20}$. Incluso, como afirma AMAYA, este control puede ir desde la redacción previa del modelo del contrato, antes de que sea puesto a disposición del consumidor, hasta la organización de un sistema de acuerdos colectivos de consumo, donde los modelos contractuales que serán utilizados para entablar relaciones contractuales, pueden ser negociados con la co-participación de empresarios y consumidores ${ }^{21}$.

La finalidad de estas asociaciones es proteger los derechos de los consumidores consagrados. En tal sentidoSOTO manifiesta que"el control se da principalmente mediante difusión de la información a los consumidores y usuarios que normalmente les es vedada por el predisponente. Ejercen presión sobre las empresas que incorporan cláusulas leoninas o abusivas en los contratos masivos, formulan denuncias ante el órgano encargado de la defensa de los consumidores, esto es, INDECOPI"22.

Por otro lado, debe precisarse que el control grupal o colectivo, en esencia tiene un carácter preventivo, en cuanto busca dejar sin efecto los posibles abusos que pueda cometer el proveedor, vigilando que los contratos de consumo no contengan cláusulas abusivas para los consumidores o contribuyendo en la elaboración de los formularios de futuros contratos a colocarse en el mercado. Sin embargo, sus alcances no se agotan con la prevención, sino también tienen facultades de defensa posterior, una vez celebrado el contrato y cuando se han evidenciado las cláusulas abusivas. En este caso, las asociaciones de consumidores actúan demandando el restablecimiento del equilibrio en las relaciones contractuales que han sido alteradas por la presencia de cláusulas abusivas y, de no ser posible, podrán solicitar la extinción del contrato celebrado con cláusulas abusivas $\mathrm{y}$, en ambos casos, podrán solicitar el resarcimiento que corresponda al consumidor.

${ }^{20}$ Cita de: REZZÓNICO, Juan Carlos; cit., p. 34.

21 Amaya Ayala, Leoni Raúl; cit., p. 55.

22 Sото CoAguila, Carlos Alberto; «Las cláusulas generales de contratación y las cláusulas abusivas en los contratos predispuestos», cit., p. 238-239. En nuestro país, es loable la enorme tarea que viene desempeñando la ASPEC, Asociación Peruana de Consumidores y Usuarios, cuya eficacia se ve plasmada en la defensa de los derechos de los consumidores. Se centra en el control de los precios y condiciones de los bienes y servicios que se ofrecen en el mercado, verificando si éstos reúnen los parámetros permitidos y que no afecten los derechos de consumidores y usuarios. No obstante sus alcances son limitados, pues solo tiene acción sobre determinadas áreas del país. 
Nuestro Código de Protección y Defensa del Consumidor ha regulado el tema en el artículo $153^{\circ}$ de una manera trascendente. En primer lugar, reconoce el alcance tuitivo de las asociaciones de consumidores en tres esferas: asociativa, individual y colectiva o difusa. En la esfera asociativa, las asociaciones de consumidores tienen alcance para proteger en forma exclusiva a sus asociados, es decir a las personas que la han constituido, los que realizan sus aportes periódicos para sustentar a la organización; vale decir, aquellos miembros que tienen la capacidad para elegir a los miembros directivos o para ser elegidos como parte de la dirección en el interior de la asociación. Por otro lado, las asociaciones de consumidores, también tienen facultades para promover acciones en defensa de aquellos consumidores particulares que les hayan otorgado poder para tal efecto. Finalmente, las asociaciones de consumidores también pueden accionar en defensa de intereses colectivos, es decir de intereses o derechos de grupos determinados de consumidores e, incluso, pueden defender intereses difusos, es decir intereses o derechos que pertenecen a los consumidores en general o comunidades indeterminadas de consumidores.

Las asociaciones de consumidores para poder ejercer efectivamente tales medios de tutela, deben estar constituidas como asociación civil sin fines de lucro, estar registrada en el libro de personas jurídicas, cumplir su finalidad de proteger, defender, informar y representar a los consumidores, no recibir financiamiento de los proveedores, entre otros requisitos señalados en los artículos $153^{\circ}$ al $159^{\circ}$ del Código de Protección y Defensa del Consumidor.

\section{c) El autocontrol del proveedor}

POLO señala que como forma de control voluntario a la figura del "control preventivo" y dentro de este a la figura del "autocontrol", que consiste en la renuncia voluntaria de las propias empresas a imponer unilateralmente sus propias condiciones, para lo cual elaboran ciertos códigos voluntarios de conducta, donde se limitan a enunciar los principios relativos a diversos tipos de condiciones que deben o no utilizarse en los contratos ${ }^{23}$.

En este caso, los agentes activos del control son los propios empresarios o proveedores, quienes por propia iniciativa, con el afán de proyectar en el mercado la imagen de una empresa respetuosa de los derechos e intereses

23 Polo, Eduardo; «Protección del Contratante Débil y Condiciones Generales de los Contratos», Editorial Civitas, Primera edición, Madrid, 1990, p. 43-44. 
de los consumidores, desarrollan programas preventivos, como una suerte de "responsabilidad social en materia de derechos del consumidor". Para ello elaboran reglamentos, directivas, procedimientos, grupos de trabajo y proveen de espacios para el acceso directo y la discusión mutua con los consumidores ${ }^{24}$.

\subsubsection{Tutela estatal del consumidor}

Aquí encontramos tres tipos de sistemas que tratan de proteger al consumidor contra las cláusulas abusivas. Estos mecanismos se agrupan en un control ex-ante y en un control ex-post. Dentro del primero grupo encontramos al control administrativo y al control legislativo, y dentro del segundo al control judicial.

\section{TUTELA ESTATAL DEL CONSUMIDOR}

\subsection{El control administrativo}

\subsubsection{Definición}

El control administrativo, es un control previo y preventivo, ejercido por la administración estatal, sea directamente o a través de la delegación de entidades sectoriales, con el fin de verificar, depurar y aprobar con antelación el contenido de las cláusulas que integrarán los futuros contratos de consumo a celebrarse por adhesión o con arreglo a cláusulas generales de contratación. Incluso, mediante este control se puede suprimir en forma previa aquellas cláusulas con contenido abusivo que puedan generar desequilibrio en las futuras relaciones contractuales. El objetivo de este mecanismo es la protección del consumidor antes de que pueda verificarse cualquier tipo de abuso o situación desventajosa que pretenda consolidar el proveedor a través del contenido contractual.

Para CÁRDENAS, el control administrativo "es el que se realiza a través de la Administración Pública con la finalidad de que ésta verifique el cumplimiento de las normas que en relación con esta modalidad de contratación han sido

\footnotetext{
${ }^{24}$ El Código de Protección y Defensa del Consumidor en su artículo $141^{\circ}$ relativo al Sistema de Arbitraje de Consumo como forma gratuita y rápida de resolver el conflicto entre consumidores y proveedores, permite que los proveedores que se adhieran a este mecanismo, puedan publicitarlo por diferentes medios de información utilizando un distintivo especial, como una suerte de emblema que representa públicamente la voluntad previa de un determinado proveedor, de que ante un conflicto con un consumidor, aquél se sujetará a esta forma de arbitraje de consumo para resolver la discrepancia.
} 
dictadas" ${ }^{\prime 25}$. En virtud de este control, sostiene FERRARA, la administración pública ejerce una congruente función de control sobre las actividades productivas y, más en particular, sobre las praxis mercantiles y negociales que emplean las empresas al entrar en contacto con los consumidores ${ }^{26}$.

DE LA PUENTE manifestaba que el control administrativo descansa en dos consideraciones. La primera consiste en que el predisponente somete a las cláusulas generales de contratación para que la administración acredite su idoneidad, tanto para regir el tráfico de masas como su capacidad para proteger debidamente los derechos de ambas partes, en especial los derechos del consumidor. La segunda consideración consiste en que al haber sido depuradas administrativamente las cláusulas generales de contratación, son convenientes para regular los contratos particulares que se celebren en base a ellas, incorporándose automáticamente a las ofertas que se formulen ${ }^{27}$.

\subsubsection{Características}

Como principales características de este control podemos indicar las siguientes:

a) Es un sistema de control previo. Los distintos procedimientos generalmente han sido constituidos para ejercer un control ex-ante de las cláusulas que pasarán a formar parte de futuros contratos de consumo a celebrarse por adhesión o con arreglo a cláusulas generales de contratación. Es previo, además, porque actúa como un filtro necesario al que deberán someterse determinados contratos antes de que pasen a formar parte del campo contractual propiamente dicho. Como postula $\mathrm{MROCH}$, sería más acertado examinar previamente la razonabilidad de las cláusulas generales en vez de hacerlo recién cuando se produce el litigio $^{28}$.

${ }^{25}$ CÁRDENAS QUIROZ, Carlos; «Las cláusulas generales de contratación y el control de las cláusulas abusivas», En: Contrato y Mercado, Gaceta Jurídica Editores, Primera edición, Lima, 2000, p. 113.

26 Cita de: AmAYA AYALA, Leoni Raúl; cit. p., 55. BORDA destaca con acierto que la aprobación administrativa sólo significa que el órgano de control no tiene nada que oponer a las condiciones generales del contrato por adhesión, pero esta función de vigilancia preventiva no supone una delegación de facultades que permita, sin más, elevar al plano legislativo las condiciones generales redactadas por una empresa, ni que les de eficacia para derogar las disposiciones imperativas que contradigan, BORDA, Alejandro; "Evolución de los derechos del consumidor en la legislación argentina", En: Instituciones de Derecho Privado. Contratación Contemporánea. Teoría General y Principios, Alterini, Atilio Aníbal; De los Mozos, José Luis y Soto Coaguila, Carlos Alberto, Directores, Editorial Themis, Bogotá-Colombia, 2001, p. 476.

27 De la Puente y Lavalle, Manuel; «El Contrato en General», Tomo I, cit., p. 746.

28 Cita de: RezzónICO, Juan Carlos; cit., p. 250. 
b) Es un control preventivo. Pues se estima que mediante un control administrativo previo podrá evitarse, en los futuros contratos de consumos a celebrarse, la existencia de cláusulas abusivas que desequilibren la relación jurídica patrimonial en desmedro del consumidor. Así lo destaca también GONZÁLES al señalar que "la ventaja que importa este sistema es que se reconoce con anticipación las cláusulas abusivas o de carácter ilícito evitando el perjuicio a las personas que contraten con arreglo a ellas" ${ }^{29}$. De esta manera, al eliminar previamente las cláusulas abusivas, se evitarán y disminuirán conflictos posteriores que se hubieran presentado de no haber actuado preventivamente un control administrativo. En el mismo sentido SCHREIBER señalaba que con este precepto se persigue un "propósito cautelatorio" en el entendido que la aprobación por la autoridad administrativa significa un filtro que evitará el abuso del contratante poderoso frente al débil, esto es, la defensa del consumidor ${ }^{30}$.

c) Es un control evaluador. Pues la administración pública tendrá que analizar cláusula por cláusula del contrato de consumo, para determinar y autorizar aquellas cláusulas que pasarán a formar parte del futuro contrato. El examen pasa por analizar tres momentos: primero, se verificarán las cláusulas que pasan el test de respeto a los derechos de las partes, la buena fe y en el contexto del contrato son acordes al equilibrio contractual; segundo, se tendrá que evaluar qué cláusulas generan alguna leve alteración al equilibro contractual pero que pueden ser reformuladas y; tercero, examinar qué cláusulas deberán ser definitivamente expulsadas del esquema contractual al verificarse su contenido abusivo en el contrato. Pasado el examen, las cláusulas serán aprobadas y por tanto el proveedor queda legitimado para emplearlas en la celebración de futuros contratos de consumo.

d) Es un sistema de control estatal. Es un mecanismo de protección encomendado a la administración pública, sea a través de las diferentes entidades de cada sector, o a través de una única instancia administrativa. Es el Estado quien se irroga la potestad de controlar preventivamente el contenido de las cláusulas en defensa de aquél considerado como débil contractual, es decir, el consumidor.

\footnotetext{
${ }^{29}$ GonZÁles BARBAdIllo, Elvira, «Comentario al artículo 1393 del Código Civil», En: Código Civil Comentado por los Cien Mejores Especialistas, Fuente de las Obligaciones, Gaceta Jurídica Editores, Lima, 2004, Tomo VII, p.347.

30 SCHREIBER PeZET, Max Arias; «Exégesis del Código Civil Peruano de 1984», Gaceta Jurídica Editores, Lima, Tomo I, 1998, p. 163.
} 


\subsubsection{Entidad competente}

El control administrativo, como ya indicamos, lo ejerce el Estado a través de la administración pública. Ahora, la delegación de ese mecanismo de control puede recaer en un ente único de control o, indistintamente, en órganos administrativos de los diferentes sectores que ameriten un control administrativo, como el sector transportes, financiero y de seguros, servicios públicos como agua, luz, teléfono, entre otros.

En cualquiera de los supuestos anteriores, sea el órgano único o cada instancia en su sector respectivo, ejercen iguales atribuciones en relación al empleo de los mecanismos que proporciona este control, depurando las cláusulas que a su criterio se estimen abusivas.

El Código de Protección y Defensa del Consumidor en su artículo 54, establece que las cláusulas generales de contratación se aprueban por la entidades administrativas competentes, dentro de las cuales encontramos a la Superintendencia Nacional de Banca y Seguros (SBS), al Organismo Supervisor de la Inversión Privada en Telecomunicaciones (OSIPTEL), el Organismo Supervisor de la Inversión Privada en Infraestructura de Transporte de Uso Público (OSITRAN), entre otros.

El artículo 349, inciso 8) de la Ley $\mathrm{N}^{\mathrm{o}}$ 26702, Ley General del Sistema Financiero y del Sistema de Seguros y Orgánica de la SBS, señala como atribución del superintendente: "Establecer las normas generales que regulen los contratos e instrumentos relacionados con las operaciones señaladas en el Título III de la Sección Segunda de la presente ley; y aprobar las cláusulas generales de contratación que le sean sometidas por las empresas sujetas a su competencia, en la forma contemplada en los artículos pertinentes del Código Civil".

Otro caso de control administrativo a cargo del Organismo Supervisor de la Inversión Privada en Telecomunicaciones -OPSITEL-, lo encontramos en el Decreto Supremo No 027-2004-MTC que aprueba el Texto Único Ordenado del Reglamento General de la Ley de Telecomunicaciones, que en su artículo $64^{\circ}$ dispone: "La prestación del servicio telefónico está sujeto a un contrato que suscribirán el concesionario y el abonado, de acuerdo a cláusulas generales de contratación aprobadas por Osiptel y publicadas en la guía de abonados".

Similar atribución tiene el Consejo Directivo del Organismo Supervisor de la Inversión Privada en Infraestructura de Trasporte de Uso Público -OSITRAN-. El Decreto Supremo No 010-2001-PCM, Reglamento General del OSITRAN, 
permite que dentro de sus funciones normativas pueda dictar reglamentos y normas de carácter general sobre determinados asuntos. Específicamente el artículo $24^{\circ}$ de dicha norma, menciona dos supuestos interesantes. En su inciso " $h$ " estipula que esta facultad normativa puede darse respecto a: " $h$ ) Condiciones de acceso a la infraestructura y a la provisión equitativa de los servicios vinculados a la misma, incluyendo la oportunidad, la continuidad y en general los términos y condiciones de contratación, pudiendo excepcionalmente aprobar los formatos de contratos, de ser ello necesario". Asimismo, también permite tal facultad en el inciso " $\mathrm{k}$ ", para normar o reglamentar "cláusulas generales de contratación aplicables a los contratos de concesión de infraestructura" 31 .

\subsubsection{El control administrativo en el Código de Protección y Defensa del Consumidor y el Código Civil}

\section{a) La aprobación administrativa de las cláusulas generales de contratación}

El Código de Protección y Defensa del Consumidor en su artículo 53, establece que el tema de las cláusulas generales de contratación se rige por sus normas y por el Código Civil.

En materia del consumidor, el artículo $54^{\circ}$ del Código de Protección y Defensa del Consumidor dispone que son las entidades administrativas las competentes para aprobar las cláusulas generales de contratación que serán utilizadas en los futuros contratos de consumo, haciendo referencia a los órganos reguladores de servicios públicos como sería el caso de OSIPTEL, OSITRAN o SUNASS. También se hace referencia al sector bancario, seguros y pensiones a través de la SBS. Es más, en el inciso 54.4 del artículo comentado, se estipula que incluso el INDECOPI puede solicitar a la Presidencia del Consejo de Ministros que designe a una autoridad en caso se detecte la necesidad de la aprobación de cláusulas generales de contratación en algún sector donde no tengan competencia alguna de las anteriores entidades administrativas.

El artículo 55 ${ }^{\circ}$ del Código de Protección y Defensa del Consumidor resulta de mucha importancia, pues establece un deber de publicidad para las entidades administrativas, debiendo difundir no solo las cláusulas generales de contratación que hayan sido aprobadas por estas entidades, sino también,

\footnotetext{
31 De acuerdo a la definición dada por la Ley en su artículo 1, se entiende por infraestructura, al sistema compuesto por obras civiles e instalaciones mecánicas, electrónicas u otras, mediante las cuales se brinda un servicio de transporte o que permiten el intercambio modal, siempre que sea de uso público, a las que se brinde acceso a los usuarios y por los cuales se cobre una prestación.
} 
el deber de difundir las cláusulas abusivas que se hayan detectado, emitiendo normas de carácter general prohibiendo su inclusión en contratos futuros.

La "difusión" de las cláusulas generales de contratación, adquiere especial relevancia jurídica, pues como veremos al analizar el Código Civil, dicho mecanismo dota a dichas cláusulas del poder para incorporarse como parte de los futuros contratos de consumo que se celebren con arreglo a ellas.

Por su parte, el Código Civil ha establecido una regulación general del control administrativo de las cláusulas generales de contratación, estableciendo en su artículo $1393^{\circ}$ que: "Las cláusulas generales de contratación aprobadas por la autoridad administrativa se incorporan automáticamente a todas las ofertas que se formulen con arreglo a ellas, sin perjuicio de lo dispuesto en el artículo 1395".

Esta norma confiere a las cláusulas generales de contratación aprobadas administrativamente, la posibilidad de formar parte de las ofertas de contratos futuros a celebrarse con arreglo a ellas. DE LA PUENTE argumentaba al respecto que "gran parte de la eficacia del sistema de las cláusulas generales de contratación radica en establecer el procedimiento de aprobación administrativa de dichas cláusulas, que confiere a las cláusulas aprobadas el poder de incorporarse automáticamente a todas las ofertas que se formulen para contratar con arreglo a ellas" ${ }^{\prime \prime 2}$.

Es decir, la aprobación administrativa tan solo es carta de pase para que las cláusulas generales se incorporen a las ofertas de contratos futuros. Pues el contrato solo tendrá lugar una vez que la oferta propuesta por el predisponente con arreglo a cláusulas generales de contratación aprobadas administrativamente, sea posteriormente aceptada por el adherente o consumidor.

\section{b) Las cláusulas generales de contratación no aprobadas administrativamente}

Un tema que es importante determinar en materia de protección del consumidor contra las cláusulas abusivas, sobre todo por los efectos que produce, es respecto a las cláusulas generales de contratación que no habiendo sido aprobadas administrativamente, por aplicación supletoria del artículo $1397^{\circ}$ del Código Civil, pueden ser incorporadas válidamente a las ofertas de contratos de consumo que se pretendan celebrar con arreglo a ellas.

\footnotetext{
32 DE LA PUENTE Y LAVALLE, Manuel; «Las cláusulas generales de contratación y la protección al consumidor», En: Contratación Privada, (Soto Coaguila, Carlos Alberto y Roxana Jiménez Vargas-Machuca: coordinadores), Editorial Jurista, Lima, 2002, p. 300.
} 
El asunto es relevante porque conforme al artículo $49^{\circ}$ del Código de Protección y Defensa del Consumidor, solamente se hallan dentro del concepto general de cláusula abusiva, aquellas cláusulas generales de contratación que no hayan sido aprobadas administrativamente y que en contra de las exigencias de la buena fe, coloquen al consumidor, en su perjuicio, en una situación de desventaja o desigualdad o anulen sus derechos.

El artículo $1397^{\circ}$ del Código Civil, alude básicamente a tres formas mediante las cuales se considera que las cláusulas generales de contratación quedan incorporadas a la oferta de un contrato particular, sin necesidad de aprobación administrativa previa: a) cuando las cláusulas generales de contratación han sido puestas en conocimiento directo de la contraparte que no ha intervenido en su formulación; b) cuando la contraparte haya podido conocer las cláusulas generales de contratación usando una diligencia ordinaria y; c) cuando se presume que la contraparte ha conocido las cláusulas generales de contratación al haber sido puestas en conocimiento del público mediante una adecuada publicidad.

Estas tres formas permiten el saneamiento de las cláusulas generales de contratación y su consecuente incorporación a la oferta del futuro contrato de consumo. Es decir, es factible mediante cualquiera de estas modalidades suplir la aprobación administrativa, pues el resultado final es el mismo: legitimar el uso de las cláusulas generales de contratación por parte del proveedor. Sin embargo, la ausencia de la autoridad administrativa como garante de la licitud de las cláusulas en estas modalidades, ha conllevado a que se tutele al consumidor frente a las cláusulas abusivas que puedan presentarse bajo estas circunstancias.

\section{Conocimiento directo de la contraparte}

En este primer supuesto parece no haber mayores inconvenientes, pues si la contraparte conoce las cláusulas generales de contratación del contrato que desea celebrar con arreglo a ellas, las cláusulas generales conocidas se incorporan a dicho contrato. Pues ha de tenerse presente, como lo describe TABOADA, que el primer paso de su incorporación, es a la oferta que se formule para celebrar los contratos particulares, oferta que una vez aceptada recién dará lugar al nacimiento de dichos contratos, momento a partir del cual las cláusulas generales de contratación adquirirán fuerza obligatoria. Antes de dicha incorporación no tienen ningún efecto obligatorio ${ }^{33}$.

\footnotetext{
33 TABOADA CÓRDOVA, Lizardo; «El contrato y los mecanismos jurídicos en los sistemas modernos de contratación», En: Academia de la Magistratura, Programa de Formación de Aspirantes-PROFA-, Tercer Curso, Módulo IV, Derecho Civil, Lima, Setiembre, 1999, p. 443.
} 
Sin embargo, se sostiene que en este caso, el predisponente tiene un deber, que es el de dar a conocer las cláusulas generales de contratación a su contraparte. Para DE LA PUENTE ${ }^{34}$, al estipulante le asiste una "carga de cognoscibilidad" que se manifiesta en dos aspectos: que la cláusula debe de existir, es decir que sea susceptible de apreciarse su contenido; y por otro lado, la cláusula debe ser inteligible, o sea que exista la posibilidad de ser entendida en su significado concreto. Paralelamente, a la contraparte se le impone el deber de informarse del contenido de las cláusulas generales de contratación, siempre que hayan sido puestas en su conocimiento.

\section{Conocimiento de la contraparte por medio de una diligencia ordinaria}

De primer orden, NATOLI señala que "diligencia" indica en abstracto la medida de atención, del cuidado, del esfuerzo psicológico que debe adoptar el deudor para cumplir la prestación de la manera establecida, es decir exactamente, en concreto, es expresión del quantum scientiae et voluntatis puesto por el deudor, un comportamiento instrumental enderezado a la obtención del resultado perseguido, determinando los medios que han de ser elegidos -no expresamente previstos, no in obligatione- reputados más idóneos o convenientes para tal fin ${ }^{35}$.

En este caso, al igual que en el supuesto anterior el ordenamiento privado impone deberes recíprocos a los futuros contratantes. Un "deber de cognoscibilidad" o "deber de facilitación" a cargo del predisponente $\mathrm{y}$, correlativamente, un "deber de información" a cargo del cliente o adherente.

En cuanto a la primera carga, el estipulante tiene el deber de dar a conocer oportunamente y en forma clara, las cláusulas generales de contratación a su contraparte. De este deber se derivan a la vez dos directivas, la oportunidad con que deben ser puestas en conocimiento del cliente las cláusulas generales de contratación y, por otro lado, que las cláusulas hayan sido formuladas de manera inteligible, capaces de ser comprendidas con facilidad por el futuro emisor de la aceptación a la oferta formulada con arreglo a dichas

\footnotetext{
${ }^{34}$ De la Puente y Lavalle, Manuel; «Cláusulas generales de contratación», En: Contrato y Mercado, Gaceta Jurídica Editores, Primera edición, Lima, 2000, p. 59-60.

35 Citado por: REZZÓNICO, Juan Carlos; cit., p. 395. Al autor alcanza un comentario interesante sobre la claridad de las cláusulas generales a que alude el art. 10 de Ley General de Consumidores y Usuarios de España, donde se exige la redacción clara y sencilla de las condiciones generales contractuales con posibilidad de su comprensión directa, sin reenvíos a textos o documentos que no se faciliten previa y simultáneamente a la conclusión del contrato. La sanción señala, puede adoptar dos vías, mediante la interpretación contra estipulatorem o contra preferetem o mediante la nulidad de dicha cláusula, Véase: DIEZ PICAZO, Luis; cit., Volumen primero, p. 377.
} 
cláusulas. La carencia de cualquiera de estas directivas afecta directamente la incorporación de las cláusulas generales de contratación, conllevando por tanto a sustentar su cuestionamiento posterior. DiEZ PICAZO aclara que no se exige un completo conocimiento de las condiciones generales por parte del adherente, "es suficiente que el predisponente haya facilitado la posibilidad de conocerlas, cualquiera que sea la forma en que ello se haya conocido"36. En este caso expresa, la carga de la prueba de la facilitación se traslada al predisponente.

La segunda carga corresponde al cliente o contraparte de las cláusulas generales de contratación, a quien se le impone el deber de conocer, de informarse diligentemente del contenido de la cláusulas generales en base a las cuales irá a contratar. La falta a ese deber de cuidado necesario, no lo exime de la consecuencia inmediata, esto es, que las cláusulas generales puestas a su disposición para su debido conocimiento, se incorporen a la oferta del contrato particular a celebrase con arreglo a ellas. Para MESSINEO, en este caso nos encontramos frente al principio de "autoresponsabilidad". Pues, el cliente no puede salvar el alcance de las cláusulas generales de contratación, sobre todo si éstas contienen cláusulas abusivas, cuando ignoró culposamente su contenido, habiendo prescindido de observar una diligencia ordinaria.

Sin embargo, pese a ello debe agregarse que el inciso 49.3 del artículo $49^{\circ}$ del Código de Protección y Defensa del Consumidor, establece que la carga de la prueba sobre la negociación individual de una determinada cláusula (aunque sea abusiva) corresponde al proveedor.

\section{Presunción de conocimiento mediante adecuada publicidad}

Por último, el artículo $1397^{\circ}$ del nuestro Código Civil establece que las cláusulas generales se reputan incorporadas a la oferta del contrato a celebrase, si el predisponente las hizo de conocimiento público mediante una adecuada publicidad. Unánimemente se considera que lo que aquí se está reconociendo es una "presunción iuris et de iure", es decir aquella que no admite prueba en contrario.

DE LA PUENTE comentando este aspecto señalaba que dentro de la moderna teoría de las presunciones no se admite a las "presunciones juris et de jure" por considerarlas que se tratan de auténticas disposiciones legales enmascaradas bajo la forma de presunciones. Más adelante anota que se considera como regla general a la "presunción juris tantum" y a la "presunción juris et de jure"

\footnotetext{
36 Diez PICAZO, Luis; cit., Volumen primero, p. 376.
} 
como la regla de excepción cuya existencia está supeditada a la mención expresa que se haga en la ley. Por tanto concluye, la regla contenida en el artículo $1397^{\circ}$ no señala expresamente que se trate de una presunción juris et de jure, por lo que ha de entenderse que estamos frente a una presunción juris tantum ${ }^{37}$.

Vistas así las cosas, y no obstante la brillante anotación de DE LA PUENTE, La Presencia De Esta Presunción Juris Et De Jure Inhabilita Cualquier posibilidad de cuestionar que no se tuvo acceso al conocimiento de las cláusulas generales de contratación publicitadas, como grafica el mismo DE LA PUENTE, sea porque el cliente acredite haberse encontrado de viaje o haber estado enfermo al momento de su publicación. Esta circunstancia es importante y debe tomarse en cuenta porque como se afirma: "No debe olvidarse que nos encontramos frente a cláusulas generales no aprobadas administrativamente, para las cuales rige la regla de que el conocimiento determina la incorporación"38.

\subsubsection{Tutela administrativa contra cláusulas abusivas:}

En caso de que las cláusulas generales de contratación contengan cláusulas abusivas, debemos diferenciar dos momentos. Cuando nos encontramos frente a cláusulas abusivas aprobadas administrativamente y cuando se trate de cláusulas abusivas que no hayan sido sometidas a aprobación administrativa.

En el primer caso, conforme al inciso 54.3 del artículo $54^{\circ}$ de la Ley de Protección y Defensa del Consumidor, la aprobación general de la cláusula general de contratación solo puede ser cuestionada en la vía judicial. El cuestionamiento de la aplicación concreta de la cláusula se hace por el consumidor directamente afectado recurriendo a la vía administrativa o judicial competente para que emita pronunciamiento en el caso concreto. El inciso 54.5 del artículo citado, impone a las entidades administrativas que hayan identificado cláusulas abusivas emitir normas de carácter general para prohibir su inclusión en contratos futuros. Es más, el artículo $55^{\circ}$ del cuerpo de leyes comentado también regula que la autoridad sectorial difunde no solo las cláusulas generales de contratación aprobadas administrativamente, sino también las cláusulas abusivas identificadas.

Por otro lado, cuando se trate de cláusulas abusivas que resultan de cláusulas generales de contratación que no hayan sido aprobadas administrativamente,

\footnotetext{
37 De la Puente y Lavalle, Manuel; «Cláusulas generales de contratación», cit., p. 59-60.

38 Ídem, p. 60.
} 
conforme lo dispone el artículo $52^{\circ}$ del Código de Protección y Defensa del Consumidor, estas cláusulas serán ineficaces, absolutas o relativas, según el supuesto de que se trate, y serán inaplicadas por la autoridad administrativa.

\subsection{El control legislativo}

\subsubsection{Definición}

El control legislativo es un mecanismo de protección estatal previo, compuesto por un conjunto de normas jurídicas que regulan los contratos celebrados por adhesión o con arreglo a cláusulas generales de contratación, estableciendo los procedimientos y condiciones para su validez, así como la determinación de las cláusulas abusivas, los medios de defensa contra dichas cláusulas y la sanción legal que corresponda, de allí su finalidad tuitiva. Además, es un "control base", pues brinda las pautas generales, principios, facultades y espacios de actuación tanto al control administrativo previo como al control judicial posterior.

POLO señala que en este caso, "es a la ley -y no a las propias empresas, a los consumidores, ni a la Administración- a quien corresponde la definición de lo que debe entenderse por cláusula abusiva y la determinación de su eficacia o fuerza obligatoria en el contrato" ${ }^{\prime 39}$.

Por medio de este control, y sobre todo si se trata de contratos de consumo celebrados por adhesión o con arreglo a cláusulas generales de contratación, el legislador tiende a tener sumo cuidado en su regulación y, atendiendo al carácter predispuesto de estas formas contractuales, el objeto principal es limitar el poder del predisponente relativizando los alcances del principio de la supletoriedad del Derecho Contractual, en virtud del cual es la voluntad de las partes la que debe primar en el contrato, y solo en aquellos espacios no regulados por ésta, intervienen las normas contractuales supliendo los vacíos dejados por los contratantes; claro está, siempre que no existan normas de carácter imperativo que niegan a las partes pactar en contra de lo que hayan dispuesto.

\footnotetext{
39 POLO, Eduardo; cit., p. 53. El autor citado complementa señalando: "El refuerzo del Derecho imperativo ha de tener por objeto, efectivamente, el limitar el poder de determinación de las partes -y correlativamente de la empresa- en cuanto al contenido del negocio, bien mediante la supresión de las normas de derecho dispositivo o su conversión en imperativas, la prohibición de determinadas cláusulas lesivas para el consumidor o usuario, la determinación completa y precisa del contenido del contrato y obligaciones de las partes, bien colmando las lagunas que se advierten en íntegros sectores de la contratación", Idem, p. 54.
} 
Al presuponerse la existencia de desequilibrio contractual en los contratos de consumo, donde existe una superioridad del proveedor en la conducción de los términos contractuales frente a la inactividad o imposibilidad del consumidor, el legislador opta por un mecanismo consistente en la reducción de las normas supletorias, elevando a la categoría de normas imperativas las normas cuya observancia normalmente quedaba a la voluntad de las partes. De esta manera el legislador reduce el espacio otorgado a las partes para acordar los términos del contrato, y que en la práctica, en el contexto de los contratos de consumo, es utilizado casi exclusivamente por el proveedor en desmedro del consumidor. De esta manera, el proveedor se hallará frente a normas imperativas contra las cuales no podrá desarrollar a su sola y plena voluntad, incorporando cláusulas abusivas en agravio del consumidor.

Un tema que no es unánime en los diversos ordenamientos jurídicos, es la ubicación de la regulación de los contratos celebrados por adhesión o con arreglo a las cláusulas generales de contratación y de las pautas concernientes al control de las cláusulas abusivas. $\mathrm{Al}$ respecto existen tres posturas, algunos países han regulado el tema en sus códigos de fondo o Códigos Civiles, otros han optado por regularlo en la legislación de protección al consumidor, otros en sus Códigos de Comercio y, otros, han regulado el tema a través de una legislación especial.

Dentro de los países que han regulado el tema en sus Códigos Civiles encontramos por ejemplo a Italia y Paraguay, entre otros. Entre los países que han regulado el tema en la Ley de Protección al Consumidor encontramos a Argentina, Brasil, México, entre otros. Los que han regulado en el Código de Comercio tenemos a Bolivia, Honduras y, los países que han regulado el asunto en leyes especiales encontramos a España, Francia, Alemania, entre otros.

En el caso peruano, incluso podemos hablar de una regulación mixta y extensiva en el tema de los contratos por adhesión y de las cláusulas generales de contratación, pues existen normas de regulación tanto en el Código Civil (véase los artículos $1391^{\circ}$ al $1401^{\circ}$ ), como en el Código de Protección y Defensa del Consumidor (véase los artículos $45^{\circ}$ al $55^{\circ}$ ).

\subsubsection{Características del control legislativo}

El sistema de control legislativo previsto en el Código de Protección y Defensa del Consumidor contra las cláusulas abusivas, reúne las siguientes características: 
a) Es un control ex-ante: El legislador prevé con antelación a la celebración del contrato de consumo particular, los posibles supuestos de cláusulas abusivas, creando una plataforma legislativa de situaciones previas que si se verifican posteriormente caen dentro de su campo de regulación. Esto importa una determinación y limitación previa, que parte del mismo texto legal, del contenido de los contratos por adhesión y de los contratos celebrados con arreglo a cláusulas generales de contratación; tal como lo hacen los artículos $49^{\circ}, 50^{\circ}$ y $51^{\circ}$ del Código de Protección y Defensa del Consumidor, que regula el concepto de cláusula abusiva, el procedimiento y los criterios para la determinación de su carácter abusivo, así como los catálogos de cláusulas abusivas y la sanción legal contra ellas.

b) Permite regular los aspectos más importantes en relación a los contratos de consumo: El legislador del Código de Protección y Defensa del Consumidor, ha definido a estos contratos (artículo $45^{\circ}$ ) estableciendo un mínimo de protección en su contenido (artículo $46^{\circ}$ ) así como los requisitos que deberán tener los contratos de consumo celebrados por adhesión o con arreglo a cláusulas generales de contratación no aprobadas administrativamente (artículo $48^{\circ}$ ). También reconoce el mecanismo de aprobación administrativa de contratos de consumo que se celebren por adhesión o con arreglo a cláusulas generales de contratación en el ámbito de los servicios públicos y el sector bancario, financiero y de seguros (artículo $54^{\circ}$ ).

c) Establece un catálogo de supuestos de cláusulas abusivas de ineficacia absoluta: Como lo estipula el artículo $50^{\circ}$ del Código de Protección y Defensa del Consumidor, también llamada "lista negra", cuya calificación del carácter "abusivo" y efecto de ineficacia absoluta, es predeterminado y estipulado por la ley, sin admitir ninguna salvedad.

d) Establece un catálogo de supuestos de cláusulas abusivas de ineficacia relativa. El artículo $51^{\circ}$ del Código de Protección y Defensa del Consumidor regula la "lista gris" de cláusulas abusivas, cuya valoración y efectos, se realizará teniendo en cuenta cada contrato en particular.

e) Otorga pautas generales al control administrativo y al control judicial: Como lo hace artículos $53^{\circ}$ a $55^{\circ}$ del Código de Protección y Defensa del Consumidor, donde se regulan las pautas de la aprobación administrativa en caso de las cláusulas generales de contratación, como lo hacen los artículos $52^{\circ}$ y $54^{\circ}$ del Código citado, que atribuyen facultades a la autoridad administrativa y permiten el cuestionamiento de las cláusulas en la vía administrativa y judicial. 


\subsubsection{Métodos de control legislativo}

Se han adoptado tres mecanismos legales para la protección contra las cláusulas abusivas: la inclusión de una cláusula general o abierta, la determinación de una lista negra de cláusulas abusivas y la adopción de una lista gris de cláusulas abusivas.

\section{a) La cláusula general}

Este método consiste en la regulación jurídica de un concepto general de cláusula abusiva con los elementos y situaciones propios que la configuran. Esta forma de regulación se basa en preceptos de alcance general como la buena fe, la equidad, la existencia de desequilibrio entre los derechos y obligaciones de las partes derivadas del contrato y que al ser de carácter general, permiten abarcar un gran número de supuestos que serán considerados como cláusulas abusivas.

REZZÓNICO alcanza que "la cláusula general o norma abierta configura un precepto amplio, una estructura de tipo que comprende, con gran generalidad, un determinado campo de hechos a los que alimenta; de tal manera que todas las cláusulas que se encuentran comprendidas dentro de esta estructura son abusivas o vejatorias" ${ }^{\prime 40}$.

El Código de Protección y Defensa del Consumidor en su artículo $49^{\circ}$ regula a la cláusula general señalando que "en los contratos por adhesión y en las cláusulas generales de contratación no aprobadas administrativamente, se consideran cláusulas abusivas y, por tanto, inexigibles todas aquellas estipulaciones no negociadas individualmente que, en contra de las exigencias de la buena fe, coloquen al consumidor, en su perjuicio, en una situación de desventaja o desigualdad o anulen sus derechos".

Como podemos apreciar, los elementos configurativos de la cláusula abusiva son el carácter no negocial de las estipulaciones, que sean contrarias a las exigencias de la buena fe y coloquen al consumidor en una situación de desventaja. Es más, el mismo dispositivo legal acotado agrega que en la evaluación de las cláusulas abusivas, se tiene en cuenta la naturaleza de los productos o servicios objeto del contrato, todas las circunstancias que concurren en el momento de su celebración, incluida la información que se haya brindado, así como todas las demás cláusulas del contrato o de otro del que este dependa.

40 ReZzónICO, Juan Carlos; cit., p. 459. 
El método de la cláusula general es regulado por Ley Alemana de Condiciones Generales de 1976 (AGB Gesetz), así como de la Directiva Europea 13/93 CEE de 1993.

POLO comentando el artículo 9 de la Ley alemana que regula la cláusula general, afirma que esta norma considera ineficaz la cláusula que sea contraria a la buena fe e irrogue un perjuicio desproporcionado a la otra parte, asimismo menciona que la buena fe y la desproporción o desequilibrio entre los derechos y obligaciones de las partes constituyen los conceptos básicos de esta norma general o abierta ${ }^{41}$.

Por su parte, GIAMPIERI comentando el artículo 3 de la Directiva Europea 13/93 CEE, que también regula una norma de alcance general, señala que este precepto contiene tres principios fundamentales que deben considerarse para valorar el carácter abusivo o vejatorio de una cláusula: a) la buena fe, b) el equilibrio contractual y, c) la negociación del contrato ${ }^{42}$.

\section{b) La lista negra de cláusulas abusivas y sus efectos}

Para SOTO la lista negra consiste "en la enumeración taxativa de una relación, cerrada o abierta, de supuestos en los que determinadas cláusulas o estipulaciones contractuales podrían declararse nulas. Esta lista es cerrada cuando los supuestos enunciados son los únicos, es decir, estamos ante una lista de numerus clausus. En cambio, es abierta cuando se permite, además de los supuestos establecidos, otros no contemplados expresamente, lo que doctrinariamente se denomina numerus apertus" ${ }^{\prime 43}$.

La lista negra reúne dos características básicas. Por un lado, comprende los casos específicos y concretos de cláusulas consideradas abusivas, y por otro, también se caracteriza por sancionar con la nulidad o ineficacia a las cláusulas abusivas que se hallen comprendidas en dichos supuestos o simplemente se las tiene por no puestas en el contrato respectivo. De allí que se sostenga que dicha sanción legal hace innecesaria la intervención judicial para determinar el carácter abusivo de las cláusulas, pues la ley ya las ha calificado como tales.

${ }^{41}$ Polo, Eduardo; cit., p. 59. Asimismo señala que este sistema se consolida prohibiendo el uso de cláusulas ilícitas o lesivas para los consumidores y usuarios, y la configuración legal de cuándo una determinada cláusula puede considerarse abusiva. Además considera dos métodos de determinación del carácter abusivo de las cláusulas: el sistema continental basado en la técnica de la cláusula general definitoria y enumeración no limitativa de supuestos concretos de cláusulas abusivas; y el sistema anglosajón, que sanciona mediante un numerus clausus ciertos supuestos de cláusulas abusivas, Ídem, p. 56.

42 Cita de: Amaya Ayala, Leoni Raúl; cit., p. 48.

43 Soto CoAguila, Carlos Alberto; «Las cláusulas generales de contratación y las cláusulas abusivas en los contratos predispuestos», cit., p. 242. 
En este sentido se señala que "la mayoría de las legislaciones prevén como principal sanción el privar de efectos contractuales a las cláusulas abusivas, de tal forma que no obliguen al adherente"44. Esta cuestión ya la habíamos analizado al tratar el tema de la sanción legal contra las cláusulas abusivas o vejatorias.

Di IORIO, estima que estas reglas de invalidez de ciertas cláusulas, podemos encontrarlas en las normas del código de fondo que controlan el objeto del acto, por ejemplo cuando éste objeto sea física y jurídicamente imposible o cuando sea contrario a las buenas costumbres o prohibido por leyes ${ }^{45}$. Este criterio puede ser perfectamente aplicado también en nuestro caso, donde serán procedentes las acciones de lesión, de excesiva onerosidad de la prestación, el abuso del derecho, entre otros medios de tutela general, que pueden aplicarse a los contratos celebrados por adhesión o con arreglo a cláusulas generales de contratación.

El Código de Protección y Defensa del Consumidor, en su artículo $50^{\circ}$, ha regulado la llamada lista negra de cláusulas abusivas, sancionándo con ineficacia absoluta a las siguientes:

a. Las que excluyan o limiten la responsabilidad del proveedor o sus dependientes por dolo o culpa, o las que trasladen la responsabilidad al consumidor por los hechos u omisiones del proveedor.

b. Las que faculten al proveedor a suspender o resolver unilateralmente un contrato, salvo disposición legal distinta o la aplicación de normas prudenciales debidamente sustentadas emitidas por la autoridad correspondiente.

c. Las que faculten al proveedor a resolver un contrato sin comunicación previa o a poner fin a un contrato de duración indeterminada sin un plazo de antelación razonable, salvo disposición legal distinta o la aplicación de normas prudenciales debidamente sustentadas emitidas por la autoridad correspondiente.

d. Las que establezcan a favor del proveedor la facultad unilateral de prorrogar o renovar el contrato.

\footnotetext{
44 POLO, Eduardo; cit., p. 64. Para Diez PICAZO, nos encontramos ante un supuesto de nulidad parcial y en este sentido sostiene que la regla de la nulidad parcial y, por consiguiente, de la conservación de la validez del contrato, comporta la necesidad de verificar una integración de éste, en la que evidentemente no juegan las cláusulas declaradas nulas, DIEZ PICAZO, Luis; cit., Volumen primero, p. 383.

45 Di Iorio, Alfredo; cit., p. 114.
} 
e. Las que excluyan o limiten los derechos legales reconocidos a los consumidores, como el derecho a efectuar pagos anticipados o prepagos, o a oponer la excepción de incumplimiento o a ejercer el derecho de retención, consignación, entre otros.

f. Las que establezcan respecto del consumidor limitaciones a la facultad de oponer excepciones procesales, limitaciones a la presentación de pruebas, inversión a la carga de la prueba, entre otros derechos concernientes al debido proceso.

g. Las que establezcan la renuncia del consumidor a formular denuncia por infracción a las normas del presente Código.

h. Las que sean contrarias o violatorias a normas de orden público o de carácter imperativo.

De allí que podamos considerar que nuestra legislación en materia de protección del consumidor, se ha adscrito al mecanismo de la lista negra como medio legislativo de control frente a las cláusulas abusivas, otorgando como sanción principal la ineficacia de dichas cláusulas.

\section{c) La lista gris de cláusulas abusivas y sus efectos}

El método de la lista gris de cláusulas abusivas también consiste en la enumeración de determinados supuestos de posibles cláusulas abusivas, pero la determinación final sobre su carácter abusivo y la sanción legal aplicable contra ellas, quedan sujetos a la determinación administrativa o judicial posterior y atendiendo a cada caso concreto.

Las cláusulas inmersas en la lista gris parten de una suerte de precalificación respecto a su carácter abusivo, pero no son sancionadas preliminarmente con la nulidad o ineficacia por la ley, sino que la sanción está sujeta a la valoración del caso concreto. Esta característica las diferencia de las cláusulas abusivas contenidas en la lista negra, pues, puede suceder que se determine su plena eficacia y a razón de ello puedan resultar plenamente válidas en el contrato. Por el contrario, si se determina administrativa o judicialmente su ineficacia, no serán válidas quedando excluida su aplicación al contrato.

El artículo 51 ${ }^{\circ}$ del Código de Protección y Defensa del Consumidor regula la lista gris de cláusulas abusivas, a las siguientes: 
a. Las que impongan obstáculos onerosos o desproporcionados para el ejercicio de los derechos reconocidos al consumidor en los contratos.

b. Las que permitan al proveedor modificar unilateralmente las condiciones y términos de un contrato de duración continuada, en perjuicio del consumidor, salvo que obedezca a motivos expresados en él y el consumidor goce del derecho a desvincularse del mismo sin penalización alguna. Lo dispuesto en el presente literal no afecta las cláusulas de adaptación de los precios a un índice de ajuste legal ni la fijación de tarifas de los servicios públicos sujetos a regulación económica.

c. Las que establezcan la prórroga automática del contrato fijando un plazo excesivamente breve para que el consumidor manifieste su voluntad de no prorrogarlo.

d. Las que establezcan cargas económicas o procedimientos engorrosos para efectuar quejas ante el proveedor, así como las que establezcan procedimientos engorrosos para proceder a la reparación del producto no idóneo, o supongan cualquier acto previo o acción por parte del consumidor que imposibilite la debida protección de sus derechos.

e. Las que permitan al proveedor delegar la ejecución de su prestación a un tercero cuando aquel fue elegido por sus cualidades personales.

f. Las que establezcan que el proveedor puede cambiar unilateralmente en perjuicio del consumidor el tipo de moneda con la que fue celebrado el contrato.

Debe preciarse que las cláusulas que se hallan dentro de la lista gris para ser consideradas plenamente "abusivas", deben atravesar por un periodo de calificación previo. Primero, son abusivas solo cuando habiéndose analizado el caso concreto, existe un pronunciamiento administrativo o judicial que las considere como abusivas. Luego, una vez determinado su carácter abusivo, corresponde aplicar la sanción legal que la ley ha previsto, es decir, la ineficacia relativa. En este caso, compartimos la opinión de SOTO al precisar que las cláusulas abusivas no deben calificarse como tales in abstracto, sino considerando cada contrato específico, pues, cabe la posibilidad que una cláusula sea manifiestamente abusiva para una de las partes en un determinado contrato, en tanto cabe que la misma cláusula pueda no ser vejatoria en otro contrato distinto ${ }^{46}$.

\footnotetext{
${ }^{46}$ Soto CoAguila, Carlos Alberto; «La contratación contemporánea, el respeto a la autonomía privada y la protección a los contratantes débiles», En: El Contrato en una Economía de Mercado, Editorial Normas Legales, Trujillo, 2004, p. 71.
} 


\subsection{El control judicial}

\subsubsection{Definición}

El control judicial, es un mecanismo de protección posterior, mediante el cual el juez tiene la potestad de resolver una controversia o incertidumbre jurídica, en torno a un contrato celebrado por adhesión o con arreglo a cláusulas generales de contratación, a petición de quien se considere agraviado con una o varias cláusulas abusivas, con la finalidad de que sean declaradas nulas o ineficaces, integrando el contenido contractual dañado y restableciendo el equilibrio perdido en la relación contractual; incluso, y de ser el caso, el juez podrá declarar la ineficacia o la nulidad del contrato en su conjunto, cuando las cláusulas abusivas lo hayan afectado en su esencia y resulta imposible su recomposición jurídica.

Este control está autorizado por la regulación del artículo $54^{\circ}$ del Código de Protección y Defensa del Consumidor, que permite el cuestionamiento judicial de las cláusulas generales de contratación aprobadas administrativamente cuando se considere que puedan contener cláusulas abusivas.

MORELlO y STIGLITZ refieren que la intervención judicial "debe considerar la presencia en estos casos de una "menor voluntad común", para conducir el esfuerzo en restablecer el equilibrio contractual destruido en un contrato caracterizado por el sometimiento de una parte a otra que concentra todo el poder negocial" 47 . De modo que en virtud de este mecanismo de protección señala REZZÓNICO, el juez interviene en la cláusula abusiva para neutralizarla y encaminarla hacia un resultado justo, borrando su condición inequitativa ${ }^{48}$.

El soporte y efectividad de la intervención judicial en el contenido abusivo de los contratos de consumo, no es otro que la regulación establecida por el Código de Protección y Defensa del Consumidor, pues a partir de ella se brinda al juzgador los instrumentos básicos para emprender la tarea del control judicial, determinando a partir de la regulación legal los supuestos de cláusulas abusivas, así como los criterios de interpretación y de integración del contrato. Pues se afirma que “este control implica la acción del legislador,

\footnotetext{
47 Cita de: CÁRdenAS Quiroz, Carlos, cit., p. 109.

48 REZZÓNICO, Juan Carlos; cit., p. 610-611. VALLESPINOS apunta en el mismo sentido cuando señala que "el magistrado deberá solucionar el perjuicio que dichas condiciones generales causan al adherente mediante la declaración de invalidez de todo el contrato, o bien, sancionando la ineficacia o modificación de la cláusulas según donde recaiga el perjuicio atendiendo a la conducta particular en cada caso (...)",VALLESPINOS, Carlos Gustavo; El Contrato por Adhesión a Condiciones Generales, Editorial Universidad, Buenos Aires, 1984., p. 328.
} 
pero será solo el juez quien podrá declarar cuáles cláusulas son abusivas y cuáles no, ya que es utópico creer que el legislador pueda imaginar todas las cláusulas potencialmente abusivas, pues requiriendo prever todas las posibilidades y restringiendo el carácter abusivo a aquellas enumeradas en una lista, el legislador da al empresario, que en sus dominios muestra una imaginación ejemplar, la oportunidad de contornear la regla"49. De allí la importancia de la relación que debe existir entre el control legislativo y el control judicial, pues la función creadora del juez solo puede desarrollarse plenamente en tanto tenga amplio amparo en la regulación legislativa previamente establecida.

\subsubsection{Características}

Sostenemos que el control judicial puede manifestar las siguientes características:

a) Es un mecanismo de control posterior. Puesto que tendrá lugar una vez que se haya verificado la celebración de un contrato por adhesión o celebrado con arreglo a cláusulas generales de contratación, y en los cuales se evidencie la presencia de cláusulas abusivas que ameriten la intervención del juzgador.

b) Es un mecanismo generado. En tanto el accionar judicial está pendiente no solo de la existencia concreta de cláusulas abusivas o de situaciones inciertas que puedan generar una litis contractual, sino que además, el control judicial solo entrará en juego a requerimiento del sujeto perjudicado con el abuso o la ambigüedad. Mientras tanto, permanece latente hasta que el consumidor solicite la intervención del juez en el caso concreto.

c) Es un mecanismo evaluador. Constatada la existencia de anomalías, vacíos, contradicciones o ambigüedad en la relación contractual debido a la presencia de cláusulas abusivas, y habiendo sido solicitada la intervención judicial, corresponde al juez la tarea de evaluar la situación concreta para determinar de qué tipo de cláusulas abusivas se trata, para luego determinar los efectos judiciales que correspondan contra dichas cláusulas; asimismo, el juzgador deberá evaluar si es necesario recurrir a los mecanismos de interpretación e integración del contrato para cubrir los vacíos, ambigüedades o contradicciones que puedan haber generado las cláusulas abusivas; $\mathrm{y}$, finalmente, deberá analizar los remedios judiciales que deben adoptarse para restablecer el equilibrio contractual o en su caso,

49 Amaya AYAla, Raúl Leoni; cit., p., 56-57. 
de no ser posible la recomposición del contrato, declarar su extinción y las consecuencias que ello genere.

d) Es un mecanismo declarativo. El juzgador deberá examinar si dichas cláusulas abusivas merecen su reprobación y, de ser así, las declarará nulas o ineficaces, y por tanto no aplicables ni exigibles en el contrato de consumo.

e) Es un mecanismo integrador y reparador. Para el caso de que el contrato celebrado por adhesión o con arreglo a cláusulas generales de contratación, se halle afectado por cláusulas abusivas y éstas hayan sido declaradas nulas o ineficaces, el espacio dejado por dichas cláusulas en la relación contractual debe ser integrado por el juez, de manera que la afectación del equilibrio contractual entre las partes debido a la presencia de las cláusulas abusivas, sea reparado y restablecido judicialmente. Como señala TANGHO, "al revisar el contrato lesivo, el juez sustituye la obligación contractual por una obligación judicial" ${ }^{20}$, quedando así subsanada la relación jurídica patrimonial nacida del contrato.

\subsubsection{Mecanismos de control judicial: criterios de interpretación de los contratos de consumo celebrados por adhesión y/o con arreglo a cláusulas generales de contratación}

La tarea de la interpretación como mecanismo del control judicial, juega un rol preponderante en lo concerniente al tema de los contratos de consumo celebrados por adhesión y/o con arreglo a cláusulas generales de contratación, pues detectada una cláusula abusiva y ordenada su expulsión del contrato, el vacío dejado por ella debe ser llenado mediante la "labor interpretativa del juez", y siempre que a consecuencia de la intervención judicial en el contrato de consumo se presenten vacíos, ambigüedades o contradicciones en el contenido contractual.

LEYVA anota que la tarea de la interpretación llanamente sirve para establecer qué se ha querido efectivamente decir con las palabras empleadas por las partes contratantes ${ }^{51}$. Para DIEZ PICAZO consiste en una tarea de indagación de la "intención" de los contratantes y de atribución de "sentido" a la declaración ${ }^{52}$.

\footnotetext{
50 Cita de: VAllespinOS, Carlos Gustavo; cit., p. 358.

51 LEYVA SAAVEDRA, José; «Las reglas de interpretación de los contratos», En: Revista Actualidad Jurídica, Gaceta Jurídica, Tomo 98, Enero 2002, p. 11.

52 Diez PICAZO, Luis, cit., Volumen primero, p. 393. De lo que se trata afirma el autor, es de reconstruir el pensamiento y la voluntad de las partes considerado en su combinación y de atribuir sentido a las
} 
Sin embargo, en los contratos de consumo celebrados por adhesión o con arreglo a cláusulas generales de contratación, qué "intención o voluntad común" puede hallarse, si se trata de contratos cuyas cláusulas han sido predispuestas por una de las partes, y que solo materializan la unívoca voluntad del proveedor. De allí que los STIGLITZ manifiesten que la intención "común" de las partes, característica de que la justamente carecen los contratos por adhesión a cláusulas generales, obliga a buscar una "compensación" 53 .

En el campo concreto del contrato, la tarea del juez en aplicación de este mecanismo de control, como sostiene CÁRDENAS ocurre en tres momentos: "en primer lugar, el juez debe verificar si las cláusulas realmente estaban incluidas en el campo contractual; en segundo término, el juez debe interpretar las cláusulas de manera estricta con el fin de restringir el ámbito de las mismas en la medida en que se aparten de normas legales supletivas $y$, finalmente, el juez debe ejercer un control sobre el contenido de las cláusulas" ${ }^{\prime 24}$.

Para realizar labor interpretativa en este tipo de contratos, se otorga al juez determinados criterios en base a los cuales pueda centrar su labor judicial. Entre estos criterios de interpretación aplicables a los contratos de consumo celebrados por adhesión o con arreglo a cláusulas generales de contratación, encontramos: el principio pro consumidor o favor debilis, el principio de la interpretatio contra stipulatorem, el principio de la buena fe, el principio de la equidad, el criterio de la cláusula prevalente, el criterio de la cláusulas más beneficiosa y el criterio de la cláusula más importante.

\section{a) Interpretación pro consumidor o favor debilis}

En el caso de los contratos de consumo, puede hablarse concretamente de una interpretación a favor del débil contractual, apoyándose en la premisa de que el consumidor se encuentra en una situación de inferioridad respecto al predisponente, derivada de su inexperiencia en el mercado y de las carencias y deficiencias en el manejo de la información.

declaraciones realizadas por los contratantes. COVIELLO señala que se acude a la interpretación cuando las partes no están de acuerdo sobre el alcance que debe atribuirse a las palabras por medio de las cuales expresaron su voluntad generando el consentimiento. Es precisamente la discrepancia sobre el alcance y contenido de las voluntades respectivas lo que motiva la necesidad de proceder a interpretar, Cita de: STIGLITZ, Rubén S. y STIGLITZ, Gabriel A.; cit., p. 73.

53 StiglitZ, Rubén S. y StiglitZ, Gabriel A.; «Contratos por Adhesión, Cláusulas Abusivas y Protección al Consumidor», Ob. cit., p. 73-74.

54 CÁRdenas Mejía, Juan Pablo; "La protección del contratante y la evolución del derecho contemporáneo", En: Revista Jurídica del Perú, Editora Normas Legales, Año LIII, Número 47, Trujillo, Junio 2003, p. 27. 
Así, en caso que una cláusula abusiva cause duda u oscuridad en un contrato celebrado por adhesión o con arreglo a cláusulas generales de contratación, el juzgador debe aplicarla en el sentido que favorezca a aquél que no haya tenido participación en la elaboración del esquema contractual, en beneficio del consumidor, pues se presume su condición de desigualdad.

DE LA PUENTE anotaba que el fundamento de esta posición es siempre imponer una sanción al predisponente por faltar al clare loqui, desde que la redacción de la estipulación dudosa es imputable exclusivamente a él, pero con una visión más positiva, pues se orienta a hacer surgir un derecho a favor de la contraparte y no crear un perjuicio al predisponente ${ }^{55}$. De modo que cabe hablar aquí de un "efecto reflejo recíproco e inverso" que generan las cláusulas abusivas usadas por el proveedor. Por un lado, las cláusulas abusivas que generan oscuridad o ambigüedad se interpretan en contra del estipulante (interpretatio contra estipulatorem) por haber faltado a su deber de hablar con claridad, y por otro, casi simultáneamente la oscuridad o ambigüedad de dichas cláusulas ha de interpretarse a favor de quien no las ha redactado (interpretación pro consumidor).

El principio pro consumidor es uno de los principios rectores de nuestro Código de Protección y Defensa del Consumidor, sustentado no solo con una base constitucional al amparo del artículo $64^{\circ}$ de nuestra Carta Magna, sino que además, es el fundamento de la interpretación en caso exista duda, en los contratos de consumo celebrados por adhesión o con arreglo a cláusulas generales de contratación.

\section{b) La interpretatio contra stipulatorem}

En virtud de este precepto, quien genera la oscuridad o la ambigüedad, debe ser penado a soportar los efectos que ello comporte. Se genera así, una suerte de acto reflejo, una circunstancia de repercusión que lleva al autor de la duda o responder por las consecuencias de aquella.

DIEZ PICAZO entiende que la interpretatio contra estipulatorem implica una sanción y a la vez una protección. Una sanción que consiste en no favorecer al estipulante que ha generado la duda o la ambigüedad con la interpretación $\mathrm{y}$, una protección, pues el hecho de no favorecer al causante de la oscuridad

\footnotetext{
55 De la Puente y Lavalle, Manuel; «El Contrato en General», cit., Tomo I, p. 824. En igual sentido entiende REZZÓNICO cuando sostiene: "decir que la interpretación se debe hacer contra quien estipuló significa establecer una ventaja para la otra parte, y correspondientemente decidir que la interpretación será a favor del deudor es afirmar que ella será de desventaja del acreedor". REZZónICO, Juan Carlos; cit., p. 607.
} 
quiere decir que se ha de favorecer al adversario ${ }^{56}$. De allí que Polo postule que "el fundamento de esta regla es el de que un hombre es responsable de las ambigüedades de sus propias expresiones y no tiene derecho alguno a inducir a otro a contratar con él bajo la suposición de que sus palabras quieren decir una cosa, mientras espera que la corte adopte una interpretación por virtud de la cual significará otra cosa que lo beneficie más..."57.

REZZÓNICO explica que la razón de la interpretación contra el estipulante se da porque no se puede imputar sino a él mismo no determinar mejor la naturaleza de la ventaja que se propone obtener ${ }^{58}$. Indudablemente, esto genera un deber a cargo de quien se atreve a predisponer unilateralmente el contrato por adhesión o con arreglo a cláusulas generales de contratación: el deber de expresarse claramente o como se conoce en la doctrina el deber de "clare loqui". En este sentido explica SALANDRA que el principio "in ambiguis contra estipulatorem" tiene su fundamento en la consideración de que quien formuló las condiciones del contrato tiene los medios a su alcance para evitar, con la claridad de la expresión, toda duda, y, si no lo ha hecho, debe soportar las consecuencias de su negligencia, impericia o mala fe" $\mathrm{fe}^{\prime \prime 2}$.

Desde el punto de vista del proveedor la "ambigüedad" de las cláusulas es el vehículo perfecto mediante el cual trata de insertar cláusulas abusivas que generen beneficios exclusivos a su favor y que, por el contrario, ocasionen perjuicios o lesión de derechos del consumidor a consecuencia de su operatividad en el contrato. Desde esta perspectiva, las cláusulas que bajo la apariencia de la ambigüedad pretenden imponer abusos en el contrato de consumo, vulneran la exigencia del deber de claridad de las cláusulas que exige el artículo $48^{\circ}$ del Código de Protección y Defensa del Consumidor y, que al tratarse de una norma imperativa, en aplicación del inciso h) del artículo $50^{\circ}$ de Código comentado, este tipo de cláusulas podrían ser consideradas judicialmente como abusivas y por ende ser excluidas del contrato al aplicarse la ineficacia.

\footnotetext{
56 Citado por: ReZzónICO, Juan Carlos; cit., p. 591-592.

57 Cita de Silva RuIZ, Pedro F.; "Contratos de adhesión, condiciones contractuales generales (Condiciones generales de los contratos o de la contratación y las cláusulas abusivas)», En: Instituciones de Derecho Privado. Contratación Contemporánea. Teoría General y Principios, (Alterini, Atilio Aníbal; De los Mozos, José Luis y Soto Coaguila, Carlos Alberto, Directores), Editorial Themis, Bogotá-Colombia, 2001, p. 55.

58 REZZÓNICO, Juan Carlos; cit., p. 589.

59 Cita de: STIGLITZ, Rubén S. y STIGLITZ, Gabriel A.; cit., p. 79. ITURRASPE señala que la oscuridad en las ideas de quien redacta, el deseo de confundir o equivocar, de ocultar tras esa falta de claridad cláusulas francamente beneficiosas para una de las partes y perjudiciales para la otra; en ocasiones tiende esa oscuridad, unida a lo abigarrado y pequeño de la escritura, a desalentar el examen o análisis previo, a forzar un no toma de conciencia. La sanción a este proceder es la interpretación en contra de los intereses del predisponente y a favor del adherente", Ídem, cit., p. 87).
} 
De esta manera, la carga impuesta al proveedor como autor del contrato de expresarse con claridad, consolida el "efecto reflejo recíproco e inverso", a que se ha hecho mención. Pues, si el proveedor al elaborar el contrato de consumo no ha tomado el debido cuidado en la forma de expresarse o ha omitido tal deber con la finalidad de obtener alguna ventaja en desmedro del consumidor, correlativamente, en virtud del acto reflejo, recaerá sobre él mismo las consecuencias de su falta de diligencia necesaria o por la omisión realizada.

\section{c) Principio de la buena fe}

La buena fe contractual u objetiva, también es otro precepto que adquiere relevancia en la tarea de la interpretación judicial. Ha de ser entendida como un precepto o modelo de comportamiento que las partes deben seguir antes, durante y después de la celebración del contrato ${ }^{60}$.

SOTO señala que la buena fe objetiva es una "regla de conducta", un "estándar jurídico de un prototipo" ${ }^{61}$, respecto al cual, los futuros contratantes deberán ajustar sus conductas, demostrando su honestidad. En términos de JIMÉNEZ, la buena fe objetiva se manifiesta como un criterio de comportamiento conscientemente asumido ${ }^{62}$. Se juzga la conducta del sujeto, a fin de determinar si alcanza el nivel exigible, es decir, si se encuentra en concordancia con las reglas admitidas acerca de lo que es recto y honesto.

Los futuros contratantes se someterán a una futura relación contractual en el entendido que cada cual observará aquél modelo de conducta que ordena un actuar dentro de ciertos márgenes de lealtad. En el caso de los contratos celebrados por adhesión o con arreglo a cláusulas generales de contratación, se afirma que el consumidor o no profesional cuando contrata con un profesional lo hace sobre la base de que éste actuará de buena fe y que redactará el contrato en términos leales, de tal forma que corresponda a lo informado y permita lograr el fin previsto ${ }^{63}$.

\footnotetext{
60 Esta manifestación de la buena fe, difiere de su correlativo, la buena subjetiva, que es aquella creencia depositada interpartes de que su común actuar es honesto y correcto, de allí que se la denomine también buena fe-creencia.

${ }^{61}$ Soto CoAguila, Carlos Alberto; «Las cláusulas generales de contratación y las cláusulas abusivas en los contratos predispuestos», cit., p. 248.

62 JimÉneZ VARGAS-MAchUCA, Roxana; «La oferta al público en el código civil y la ley de protección al consumidor», En: Instituciones de Derecho Privado. Contratación Contemporánea. Teoría General y Principios, (Alterini, Atilio; De los Mozos, José Luis y Carlos Soto - Directores), Temis y Palestra Editores, Bogotá, Primera edición, Tomo I, 2000, p. 525.

63 Cárdenas Mejía, Carlos; cit., p. 29.
} 
Mediante los alcances de la buena fe contractual, el juzgador al entrar en la esfera de la relación jurídica de un determinado contrato, puede evaluar con gran amplitud de criterio, si la conducta desplegada por las partes antes o durante el contrato, se ajusta a los cánones de la buena fe, pudiendo determinar además, cuál de los contratantes actuó de mala fe. Por ello, si se determina que el predisponente actuó de mala fe, de una manera ajena a un comportamiento leal y honesto, al incluir cláusulas abusivas que no solo causan abuso injustificado en su contraparte sino que además conllevan al desequilibrio contractual; el juez no tendrá mayor reparo que condenar aquella actitud de malicia, pudiendo además, restablecer el equilibrio contractual.

Debe aclarase que el juez solo puede intervenir cuando el que se considere agraviado lo solicite. Pues ha de tenerse en consideración que el contrato y las situaciones que se generen en torno a él, competen solo las partes; por ello, es correcto que quien considere que el contrato le causa cierto abuso en sus derechos $\mathrm{u}$ obligaciones, someta al control judicial a la relación jurídica contractual para que el juzgador pueda contrastar si la conducta de las partes ha respetado la buena fe contractual o la ha vulnerado.

\section{d) La cláusula prevalente}

Mientras que la interpretación contra stipulatorem, la interpretación favor debilis o la buena fe contractual, tienen aplicación extensiva a todas las esferas contractuales, la cláusula prevalente se reserva para ser aplicada solo frente a esquemas contractuales elaborados a instancia de una de las partes, como sucede en los contratos de consumo celebrados por adhesión o con arreglo a cláusulas generales de contratación.

En virtud de este mecanismo de interpretación, como alcanza DiEz PICAzo, cuando haya discrepancia entre el contenido de una condición general y de una cláusula particular, habrá de estarse a lo que disponga esta última ${ }^{64}$. Entonces, cuando el juez tenga en frente una cláusula particular que incluso regule aspectos que ya han sido previstos por las cláusulas dictadas al arbitrio del predisponente, deberá interpretar que la cláusula particular al ser voluntad de las partes, prevalece frente a la cláusula general de contratación.

La cláusula particular es entendida como aquella que ha surgido producto de la voluntad de ambos contratantes. Pues, cuando hablamos de contratos de consumo celebrados por adhesión o con arreglo a cláusulas generales de

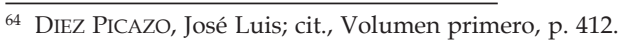


contratación, pese a que por lo general se trata de esquemas elaborados en forma unilateral, cabe la posibilidad de que determinados aspectos puedan ser objeto de negociación particular por ambos contratantes. En este contexto, se acoge como fundamento que la cláusula particular, surgida del común acuerdo de las partes y atendiendo a la naturaleza unilateral de los esquemas contractuales predispuestos, sería la que mejor refleja la intención de ambas partes.

\section{e) La cláusula más beneficiosa}

Al igual que en el caso anterior, la cláusula más beneficiosa adquiere trascendencia en los contratos de consumo como contratos predispuestos. Para Diez PicAzo la regla de la condición más beneficiosa apunta que en caso de divergencia entre una condición general y una cláusula particular, se aplicará la que resulte más beneficiosa para el adherente, esta condición más beneficiosa puede dirigirse por ejemplo ampliar los derechos del adherente o reducir de sus obligaciones, cargas y deberes ${ }^{65}$.

En este caso, utilizando un criterio de benignidad, al igual que en el caso de la interpretación a favor del consumidor, el juzgador también debe interpretar en el sentido más beneficioso para él. Aunque a nuestro parecer, la cláusula más beneficiosa solo tendrá cabida en tanto se evidencie que la cláusula particular es perjudicial para el adherente en contraste con la cláusula general, de manera que se opte por aplicar ésta última por estimarse menos perjudicial. De allí que se pueda sostener que la cláusula más beneficiosa constituye un suerte de filtro de la cláusula prevalente en aras de establecer un medio adecuado de protección contra posibles abusos que no descartan utilizar, como vía de acceso al contrato, a la cláusula particular.

Esta apreciación es complementada por ALFARO cuando señala que si el juzgador no puede determinar entre la cláusula general y la particular, cuál cláusula es la más beneficiosa, se preferirá la cláusula particular sobre la general $^{66}$.

\section{f) La cláusula más importante}

Aunque este criterio tiene data doctrinaria, puede también servir como mecanismo judicial de interpretación, sobre todo de las cláusulas generales de contratación.

\footnotetext{
65 Ídem, p. 412-413.

${ }^{66}$ Citado por: SAAVEdRA LeYVA, José; cit., p. 25.
} 
DiEZ PICAZO señala que este método tiene lugar cuando se presente un conflicto dentro de las propias cláusulas generales de contratación; en este supuesto, se preferirán aquellas cláusulas generales que trasciendan en la economía del contrato o que constituyan el núcleo central de las prestaciones contractuales $^{67}$.

En este caso, ha de aplicarse la cláusula más importante teniendo en cuenta los otros principios garantistas del estatus de consumidor, como el principio pro consumidor; en este sentido, los vacíos, ambigüedades o contradicciones causadas por la presencia de cláusulas abusivas, deben interpretarse a favor de los intereses y derechos del consumidor.

\section{CONCLUSIONES}

5.1 El fundamento de la tutela del consumidor en los contratos de consumo celebrados por adhesión o con arreglo a cláusulas generales de contratación, radica en la facultad que tiene el proveedor para formular unilateralmente el contenido contractual y la diferencia en el manejo y acceso a la información, también conocido como asimetría informativa; ambas situaciones colocan al consumidor en una situación de debilidad contractual, que es aprovechada por el proveedor para incluir en el contenido del contrato de consumo cláusulas abusivas que hacen más evidentes las diferencias entre las partes y que terminan por desequilibrar la gama de derechos y obligaciones.

5.2 Las cláusulas abusivas generan en un contrato de consumo celebrado por adhesión o con arreglo a cláusulas generales de contratación, situaciones de desequilibrio o desigualdad, reduciendo, limitando o eliminando por completo los derechos del consumidor; aumentando o haciendo excesivamente onerosas sus cargas y obligaciones contractuales o, por el contrario, aumentando o concediendo mayores facultades, beneficios o derechos al proveedor, o limitando, excluyendo o reduciendo sus deberes u obligaciones contractuales. La presencia de las cláusulas abusivas en la esfera contractual justifica la actuación de distintos mecanismos de tutela del consumidor.

5.3 Existen mecanismos de tutela autónoma o autotutela, mediante los cuales son las mismas partes intervinientes en el contrato de consumo las que buscan establecer mecanismos de autoprotección; la que será individual

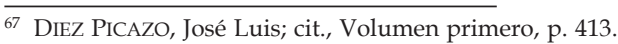


cuando el consumidor directamente perjudicado haga efectivos sus derechos vulnerados ante las instancias correspondientes; colectiva, cuando son las asociaciones de consumidores $\mathrm{u}$ organizaciones las que encargan de la defensa de los consumidores en forma colectiva, e incluso existe el autocontrol del proveedor, mediante el cual son los proveedores los que realizan una serie de acciones preventivas y de acceso para defender los derechos e intereses de los consumidores.

5.4 A cargo del Estado encontramos tres mecanismos de tutela del consumidor. El control administrativo, donde son las entidades de cada sector estatal las que de manera previa han implementado procedimientos de aprobación de cláusulas contractuales con la finalidad de detectar y expulsar a las cláusulas abusivas de los futuros contratos de consumo. El control legislativo, comprende una red normativa donde se definen principios, preceptos generales para definir a las cláusulas abusivas, la lista negra de cláusulas abusivas sancionadas con la ineficacia absoluta, la lista gris de cláusulas abusivas cuya ineficacia relativa dependerá del caso concreto, así como normas generales que sirven de base para los mecanismos de tutela administrativa y judicial. Finalmente, el control judicial que mediante la intervención del juez en un conflicto generado por cláusulas abusivas, busca reconocer y catalogar a éstas dentro de los preceptos legalmente establecidos, para luego aplicar la ineficacia absoluta o relativa que corresponda, e incluso, los vacíos, ambigüedades o contradicciones causados por la expulsión judicial de las cláusulas abusivas, podrán ser reparadas e integradas, acudiendo a los principios de interpretación del contrato, como el principio pro consumidor, la interpretatio contra stipulatorem, el principio de la buena fe, entre otros. 


\section{REFERENCIAS BIBLIOGRAFICAS}

ALPA, Guido; "Derecho del Consumidor". Gaceta Jurídica Editores, Juan Espinoza Espinoza - traductor, Lima, 2004.

AMAYA AYALA, Leoni Raúl; “La letra pequeña que nadie lee. Sistemas de control contra las cláusulas abusivas". En: Revista Actualidad Jurídica, Gaceta Jurídica, Tomo 120, Lima, Noviembre 2003.

BORDA, Alejandro; "Evolución de los derechos del consumidor en la legislación argentina". En: Instituciones de Derecho Privado. Contratación Contemporánea. Teoría General y Principios. Alterini, Atilio Aníbal; De los Mozos, José Luis y Carlos Alberto Soto Coaguila, Directores. Editorial Themis, Bogotá-Colombia, 2001.

CÁRDENAS MEjÍA, Juan Pablo; “La protección del contratante y la evolución del derecho contemporáneo", En: Revista Jurídica del Perú, Editora Normas Legales, Año LIII, Número 47, Trujillo, Junio 2003.

CÁRDENAS QUIROZ, Carlos; “Las cláusulas generales de contratación y el control de las cláusulas abusivas". En: Contrato y Mercado, Gaceta Jurídica Editores, Primera edición, Lima, 2000.

De Castro y Bravo, Federico; “Las Condiciones Generales de los Contratos y la Eficacia de las Leyes". Segunda edición, Editorial Civitas, Madrid, 1987.

De la Puente y Lavalle, Manuel; "Cláusulas generales de contratación". En: Contrato y Mercado. Gaceta Jurídica Editores, Primera edición, Lima, 2000.

De la Puente Y Lavalle, Manuel; "El Contrato en General". Palestra Editores, Lima, Tomo I, 2001.

De la Puente y LaVAlLe, Manuel; “Las cláusulas generales de contratación y la protección al consumidor". En: Contratación Privada, (Soto Coaguila, Carlos Alberto y Roxana Jiménez Vargas-Machuca: coordinadores). Editorial Jurista, Lima, 2002.

DI IORIO, Alfredo J.; "Las cláusulas generales de contratación en el código civil peruano y el ordenamiento jurídico latinoamericano". En: El Código Civil Peruano y el Sistema Jurídico Latinoamericano. Editorial Cultural Cuzco, Lima, 1985. 
DieZ PICAZO, Luis; "Fundamentos de Derecho Civil Patrimonial". Quinta edición, Editorial Civitas, Madrid, Volumen primero, 1996.

GALDÓS, Jorge Mario; “El principio favor débilis en materia contractual. Algunas aproximaciones en el derecho argentino". En: Contratación Privada, (Soto Coaguila, Carlos Alberto y Roxana Jiménez Vargas-Machuca: coordinadores), Editorial Jurista, Lima-Perú, 2002.

GONZÁLES BARBADILlo, Elvira, "Comentario al artículo 1393 del Código Civil". En: Código Civil Comentado por los Cien Mejores Especialistas, Fuente de las Obligaciones, Gaceta Jurídica Editores, Lima, Tomo VII, 2004.

JiMÉNEZ VARGAS-MACHUCA, Roxana; “La oferta al público en el código civil y la ley de protección al consumidor". En: Instituciones de Derecho Privado. Contratación Contemporánea. Teoría General y Principios, (Alterini, Atilio, De los Mozos, José Luis y Soto, Carlos - Directores), Temis y Palestra Editores, Bogota, Primera edición, Tomo I, 2000.

LEYVA SAAVEDRA, José; "Las reglas de interpretación de los contratos". En: Revista Actualidad Jurídica, Gaceta Jurídica, Tomo 98, Enero 2002.

MORALES HeRVIAS, Rómulo; "La definición del contrato de consumo en el Código de Protección y Defensa del Consumidor". En: Actualidad Jurídica, Gaceta Jurídica Editores, Setiembre, 2010.

POLO, Eduardo; "Protección del Contratante Débil y Condiciones Generales de los Contratos", Editorial Civitas, Primera edición, Madrid, 1990.

ReZZONICO, Juan Carlos; “Contratos con Cláusulas Predispuestas. Condiciones Negociales Generales". Editorial Astrea, Buenos Aires, 1987.

Schreiber Pezet, Max Arias; "Exégesis del Código Civil Peruano de 1984". Gaceta Jurídica Editores, Lima, Tomo I, 1998.

Silva Ruiz, Pedro F.; "Contratos de adhesión, condiciones contractuales generales (Condiciones generales de los contratos o de la contratación y las cláusulas abusivas)", En: Instituciones de Derecho Privado. Contratación Contemporánea. Teoría General y Principios, (Alterini, Atilio Aníbal; De los Mozos, José Luis y Carlos Alberto Soto Coaguila, Directores). Editorial Themis, Bogotá-Colombia, 2001, p. 55. 
Soto CoAguila, Carlos Alberto; “Las cláusulas generales de contratación y las cláusulas abusivas en los contratos predispuestos", En: Contratación Privada, (Soto Coaguila, Carlos Alberto y Roxana Jiménez Vargas-Machuca: coordinadores), Editorial Jurista, Lima, 2002.

SOTO COAGUILA, Carlos Alberto; “La contratación contemporánea, el respeto a la autonomía privada y la protección a los contratantes débiles", En: El Contrato en una Economía de Mercado. Editorial Normas Legales, Trujillo, 2004.

STigLiTZ, Rubén S. y STigliTZ, Gabriel A.; “Contratos por Adhesión, Cláusulas Abusivas y Protección al Consumidor". Editorial Depalma, Argentina, 1985.

TABOADA CóRDOVA, Lizardo; “El contrato y los mecanismos jurídicos en los sistemas modernos de contratación". En: Academia de la Magistratura, Programa de Formación de Aspirantes -PROFA-, Tercer Curso, Módulo IV, Derecho Civil. Lima, Setiembre, 1999.

VAllesPinOS, Carlos Gustavo; "El Contrato por Adhesión a Condiciones Generales", Editorial Universidad, Buenos Aires, 1984. 